\title{
Two specific drugs, BMS-34554I and purvalanol A induce apoptosis of HTLV-I infected cells through inhibition of the NF-kappaB and cell cycle pathways
}

\author{
Emmanuel Agbottah1, Wen-I Yeh1, Reem Berro1, Zachary Klase ${ }^{1}$, \\ Caitlin Pedati ${ }^{1}$, Kyelne Kehn-Hall ${ }^{1}$, Weilin $\mathrm{Wu}^{1}$ and Fatah Kashanchi*1,2,3
}

\begin{abstract}
Address: ${ }^{1}$ Department of Microbiology and tropical Medicine and Department of Biochemistry and Molecular Biology, The George Washington University School of Medicine, Washington, District of Columbia 20037, USA, ${ }^{2}$ Department of Microbiology, Institute for Proteomics Technology and Applications, The George Washington University, Washington, District of Columbia 20037, USA and ${ }^{3}$ The Institute for Genomic Research, TIGR, Rockville, Maryland 20850, USA
\end{abstract}

Email: Emmanuel Agbottah - bcmeta@gwumc.edu; Wen-I Yeh - jennyyeh@gwu.edu; Reem Berro - ramroom@gmail.com; Zachary Klase - bcmzak@gwumc.edu; Caitlin Pedati - bcmcsp@gwumc.edu; Kyelne Kehn-Hall - bcmkwk@gwumc.edu; Weilin Wu - bcmwxw@gwumc.edu; Fatah Kashanchi* - bcmfxk@gwumc.edu

* Corresponding author

Published: 10 June 2008

AIDS Research and Therapy 2008, 5:12 doi:10.1 I86/1742-6405-5-12
Received: 28 November 2007

Accepted: 10 June 2008

This article is available from: http://www.aidsrestherapy.com/content/5/I/I2

(c) 2008 Agbottah et al; licensee BioMed Central Ltd.

This is an Open Access article distributed under the terms of the Creative Commons Attribution License (http://creativecommons.org/licenses/by/2.0), which permits unrestricted use, distribution, and reproduction in any medium, provided the original work is properly cited.

\begin{abstract}
Human T-cell leukemia virus type-I (HTLV-I) induces adult T-cell leukemia/lymphoma (ATL/L), a fatal lymphoproliferative disorder, and HTLV-I-associated myelopathy/tropical spastic paraparesis (HAM/TSP), a chronic progressive disease of the central nervous system after a long period of latent infection. Although the mechanism of transformation and leukemogenesis is not fully elucidated, there is evidence to suggest that the viral oncoprotein Tax plays a crucial role in these processes through the regulation of several pathways including NF-kB and the cell cycle pathways. The observation that NF-KB, which is strongly induced by Tax, is indispensable for the maintenance of the malignant phenotype of HTLV-I by regulating the expression of various genes involved in cell cycle regulation and inhibition of apoptosis provides a possible molecular target for these infected cells. To develop potential new therapeutic strategies for HTLV-I infected cells, in this present study, we initially screened a battery of NF-KB and CDK inhibitors (total of 35 compounds) to examine their effects on the growth and survival of infected T-cell lines. Two drugs namely BMS34554I and Purvalanol A exhibited higher levels of growth inhibition and apoptosis in infected cell as compared to uninfected cells. BMS-34554I inhibited IKK $\beta$ kinase activity from HTLV-I infected cells with an $\mathrm{IC}_{50}$ (the $50 \%$ of inhibitory concentration) value of $50 \mathrm{nM}$ compared to $500 \mathrm{nM}$ from control cells as measured by in vitro kinase assays. The effects of Purvalanol $A$ were associated with suppression of CDK2/cyclin E complex activity as previously shown by us. Combination of both BMS-34554I and Purvalanol A showed a reduced level of HTLV-I pl9 Gag production in cell culture. The apparent apoptosis in these infected cells were associated with increased caspase-3 activity and PARP cleavage. The potent and selective apoptotic effects of these drugs suggest that both BMS-34554I and Purvalanol A, which target both NF-KB and CDK complex and the GI/S border, might be promising new agents in the treatment of these infected patients.
\end{abstract}




\section{Background}

Human T-cell leukemia virus type 1 (HTLV-1) is associated with aggressive adult T-cell leukemia (ATL) and HTLV-1-associated myelopathy/tropical spastic paraparesis (HAM/TSP) [1]. ATL arises after a long latent period of over 50 years and involves with a multi-step mechanism of tumorigenesis [2]. The transforming ability of HTLV-1 is primarily due to the viral oncoprotein, Tax [3]. Tax not only transactivates viral genes by binding to CREB but also activates cellular transcriptional factors including nuclear factor kappa B (NF- $\mathrm{B})$, cyclic AMP responsive element, CREB-binding protein, TATA-binding protein and TFIIA [4-14]. Acute ATL is an aggressive leukemia with a median survival of only 6 months and a projected 4 -year survival of about 5\% [2].

$\mathrm{NF}-\kappa \mathrm{B}$ transcription factor plays a crucial roles in tumorigenesis and tumor development $[15,16]$. NF- $\kappa B$ transcription factor controls the expression of genes involved cell cycle regulation and apoptosis, such as cyclin $E, b c l-2, b c l-$ $x_{L}, c$-IAPs, survivin, and XIAP [16-18]. Vertebrate NF- $\kappa \mathrm{B}$ transcription complexes can be any of a variety of homoand heterodimers formed by the subunits p105/p50, p100/p52, c-Rel, p65 (RelA) and RelB [19]. There are multiple pathways to activate NF- $\mathrm{BB}$. The two most common pathways are the canonical and the non-canonical pathways $[20,21]$. In the canonical pathway, proceeding the stimulation of TNF-R, the activated IкB kinase (IKK) complex containing IKK $\alpha / \mathrm{IKK} \beta / \mathrm{NEMO}$ phosphorylates inhib-

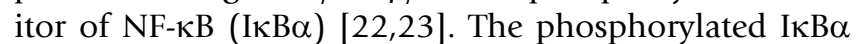
(Ser32/S36) is then ubiquitinated and degraded, which allows NF- $\kappa \mathrm{B}$ (p50-p65) to enter the nucleus where it regulates the expression of specific genes [24]. In the noncanonical pathway, the IKK complex with two IKK $\alpha$ subunits is activated through NIK by other stimuli such as lymphotoxin $\beta$ (LT $\beta$ ) and CD40 ligand, and mediates the processing of NF- $\kappa$ B complex to p52/RelB $[25,26]$. This IKK complex then phosphorylates p100 at C-terminal domain and promotes the ubiquitination of p100 and the proteasomal processing of the complex to p52/RelB [2729].

A number of reports have elucidated that the HTLV-1infected T-cells are associated with constitutively activated $\mathrm{NF}-\kappa \mathrm{B}$ and its involvement in tumorigenesis $[25,26,30,31]$. Tax is known to activate NF- $\kappa B$ by stimulating IKK complex in both canonical and non-canonical pathways by interacting with NEMO [32-35]. Tax is also reported to directly bind to and activated NF- $\mathrm{B}[4]$. The role of various transcription factors in tumorigenesis has previously been described [36]. NF- $\kappa \mathrm{B}$ and AP-1 have recently been implicated in cell survival and proliferation pathways. The NF- $\kappa$ B pathway is activated in ATL cells that do not express Tax, although the mechanism of activation remains unknown [37]. One of the potential mechanisms by which these cells could develop resistance to apoptosis is through the activation of NF- $\mathrm{B}[38]$. From this point of view, NF- $\kappa \mathrm{B}$ has become an attractive target for therapeutic intervention. Indeed, inhibition of the NF- $\kappa B$ pathway by Bay 11-7082, an irreversible inhibitor of $\mathrm{I} \kappa \mathrm{B} \alpha$ phosphorylation [25,39], by dehydroximethylepoxy-quinomicin, an inhibitor of nuclear translocation of p65, a

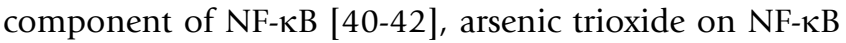
$[43,44]$. and by bortezomib, a proteasome inhibitor [45], induced apoptosis of HTLV-I-infected T-cells and ATL cells, suggesting that inhibitors of NF- $\kappa \mathrm{B}$ may be effective targets against ATL cells in vivo.

In addition to the regulation of NF- $\kappa \mathrm{B}$ pathway, viral transactivator Tax provides some initial alternation in cell cycle progression to the proliferation of viruses. HTLV-1 and/or Tax-expressing cells have altered expression of some cell cycle-associated genes and accelerate cell cycle progression in $G_{1}$ phase [46-50]. Tax targets cell cycle regulators such as p53, cyclin dependent kinases (CDKs) 4 and 6, cyclin D2, and CDK inhibitors p21waf1 and p16 INK4A [51-57]. Tax expression also results in transcriptional activation of cyclin E and CDK2 complex [58-61]. In addition, the cyclin E/CDK2 kinase activity is shown to be increased in HTLV-1 infected cells [62].

Currently there is no accepted curative therapy for ATL or HAM/TSP and the conditions, at least in the ATL, often progresses to death with a median survival time of 13 months [63]. The prognosis of this aggressive stage remains poor, and death is usually due to severe infection or hypercalcemia, often associated with resistance to intensive, combined chemotherapy. Therefore, the establishment of new therapeutic strategies for HTLV-1 infected cells is deemed critical. Due to the presence of highly activated NF- $\kappa$ B pathway and tightly controlled cell cycle progression the infected cells rely on these two mechanisms for its survival and possibly progeny formation. In an effort to find novel inhibitors, we initially screened thirtyfive inhibitors targeting these two pathways to examine their effect on cell growth. Two inhibitors BMS-345541 and Purvalanol A showed the best selectivity in inhibiting HTLV-1 infected, but not uninfected, cells. Utilizing a series of biochemical assays, we determined that BMS345541 inhibited IKK $\beta$ activity in vitro and induced higher level of apoptosis in infected cells. Finally, the efficacy of combination of both BMS-345541 and Purvalanol A in inhibiting HTLV-1 infected cells was tested. Collectively, understanding the inhibition mechanism, efficiency and the combined effects of both BMS-345541 and Purvalanol A will help gain better insights and establish novel new therapeutic approaches for HTLV-1 infected patients. 


\section{Results \\ Screening of various inhibitors on HTLV-I infected and uninfected cells}

Despite its tight control in normal T cells, NF- $\mathrm{BB}$ is constitutively activated in both HTLV-I-transformed T-cell lines and freshly isolated ATL cells suggesting that activation of $\mathrm{NF}-\kappa \mathrm{B}$ is an important part of the oncogenic mechanism of HTLV-I. This pathologic action may largely rely on the viral transforming protein Tax, at least for many of the cell lines to date that are isolated for in vitro analysis and not necessarily are ATL samples, which also up-regulates the expressions and activities of cyclin E/CDK2 which is important in cell cycle transition from $G_{1}$ to $S$ phase.

Most importantly, IKK has been established as a cellular target of Tax and an essential component in Tax-mediated NF- $\kappa \mathrm{B}$ signaling in both canonical and non-canonical pathways. Therefore, we reasoned that the specific targeting of both the NF- $\kappa \mathrm{B}$ signaling and cell cycle regulators with drugs might provide better insights into how to inhibit HTLV-1 infected cells. We sought to identify the targets of a range of NF- $\kappa \mathrm{B}$ and CDK inhibitors in HTLV-1 infected and uninfected cells by culturing MT-2, MT-4, C8166, c10/MJ and uninfected CEM and Jurkat T-cells $\left(0.5 \times 10^{6}\right.$ cells/well $)$ in media with inhibitor concentrations ranging from $0,0.01,0.1,1$, and $10 \mu \mathrm{M}$. Cells were treated for 48 hours and the level of growth inhibition was estimated using trypan blue method. Results from 35 drugs that inhibit various CDKs and IKKs are shown in Table 1 where a number of drugs inhibited HTLV-1 infected cells much more efficiently than uninfected cells. Among the top two candidates that inhibited HTLV-1 infected cells were BMS-345541 (4(2'-aminoethyl)amino1,8-dimethylimidazo(1,2-a)quinoxaline) and Purvalanol A. BMS-345541 is a selective inhibitor of IKK $\beta$ at $\mathrm{IC}_{50}$ of $0.3 \mu \mathrm{M}$ and to a lesser extent an inhibitor of IKK $\alpha$ at $\mathrm{IC}_{50}$ of $4 \mu \mathrm{M}[64,65]$. All drugs were further tested at $10 \mu \mathrm{M}$ concentration to effectively compare these different classes of inhibitors against one another. In Table 1, they are ranked as high, moderate, and poor inhibitors and the reported activities of these molecules against variety of CDKs and IKKs are indicated in the right-hand column. Collectively, these data indicate that initial cell based survival screening assays may be an effective tool in isolating drugs that are more selective against HTLV-1 infected cells as compared to control uninfected cells.

\section{Effect of BMS-34554I on IKK $\beta$ in infected and uninfected cells}

We next focused our attention on BMS-345541 and asked whether this drug could inhibit the IKK $\beta$ kinase activity on its substrate IKB $\alpha$. We immunoprecipitated (IP) IKK $\beta$ from both CEM (uninfected) and C8166 (infected) cells and used them in an in vitro kinase assays in the presence or absence of BMS-345541 (1.0 $\mu \mathrm{M})$. Results are shown in
Figure 1A where C8166 cells had far stronger IKK $\beta$ kinase activity as compared to CEM cells (compare lanes 2 to 4 ). Active kinases that were incubated with BMS-345541 showed a reduction of activity from both infected and uninfected cell extracts. However, the inhibition was much more dramatic with kinases isolated from HTLV-1 infected cells. We next titrated various levels of BMS345541 for both kinases in our in vitro assay. Results are shown in Panel B where 0.01, 0.1, and $1.0 \mu \mathrm{M}$ of BMS345541 were used for a complete range of titrations. Interestingly, at $0.1 \mu \mathrm{M}$ there was a significant reduction in the kinase activity from infected cells (lane 4 compared to lane 9). A control drug, Purvalanol A, which is a CDK inhibitor, did not inhibit the IKK $\beta$ kinase activity obtained from infected cells. Collectively, these results indicate that IKK $\beta$ from infected cells is much more sensitive to BMS-345541 as compared to IKK $\beta$ from uninfected cells.

\section{Induction of apoptosis in HTLV-I infected cells by BMS- 34554 I}

Resistance to cell apoptosis is one of the mechanisms that is important and is also required for the immortalization of T cells $[63,66]$. NF- $\kappa \mathrm{B}$ signaling pathway is the survival pathway activated by HTLV-1 in order to keep the host cell active $[67,68]$. BMS-345541 targets IKK $\beta$ subunit which is responsible for activation of the NF- $\kappa \mathrm{B}$ pathway $[64,65]$. To determine whether BMS-345541 can inhibit NF- $\kappa$ B pathway and induce apoptosis in HTLV-1 infected cells, we analyzed the level of apoptotic markers such as caspase- 3 and PARP in both infected and uninfected cells. Caspase- 3 is a member of cysteine protease and plays a key role in apoptosis [69]. When apoptosis is activated, the inactive pro-caspase- 3 is processed into active large (17 kD) and small (12 kD) subunits [70]. PARP, poly(ADP-ribose) polymerase, is also an apoptosis marker that is cleaved from precursor form (116 kD) into active form $(85 \mathrm{kD})$ by active caspase- 3 during apoptosis [71-73]. Results in Figure 2A are Western blots that show titration of BMS-345541 in two infected and one uninfected cells. Samples were treated for 48 hours and extracts were made for Western blotting. The top panel shows the caspase Western and a gradual increase of p17 form in MT-2 cells as well as C8166 cells in concentrations between 0.5 and $1.0 \mu \mathrm{M}$. There was no change in the actin levels in any of the samples treated. Panel B shows the results of the Annexin V staining where live cells are represented at the bottom right corner box in each panel. All three samples were treated with $0.1 \mu \mathrm{M}$ of BMS-345541 and stained for the presence of live and apoptotic cells. Interestingly both MT-2 and C8166 cells showed presence of few live cells as compared to CEM cells when treated with BMS-345541. Collectively, these data indicate that low concentrations of IKK $\beta$ inhibitor can apoptosis HTLV- 
Table I: Screening of Various CDK and NFkB/IKK Inhibitors and Related Molecules for HTLV-I Cell Killing

\begin{tabular}{|c|c|c|c|c|c|c|c|c|c|}
\hline \multirow[t]{2}{*}{ Selectivity } & \multirow[t]{2}{*}{ Name } & & \multirow[t]{2}{*}{ MT-2 } & MT-4 & C8166 & $\mathrm{CIO} / \mathrm{MJ}$ & CEM & Jurkat & Reported activities of \\
\hline & & & & \multicolumn{2}{|c|}{ Infected } & \multicolumn{3}{|c|}{ Uninfected } & \\
\hline \multirow[t]{8}{*}{ High } & BMS-34554I & (10 uM) & $++++*$ & +++ & +++ & + & $-* *$ & - & IKK-I(4), IKK-2(0.3) \\
\hline & Purvalanol A & ( 10 uM) & ++++ & ++ & ++ & - & - & - & $\begin{array}{l}\text { CDKI }(4), \text { CDK2(70), } \\
\text { CDK } 5(75)\end{array}$ \\
\hline & Indirubin-3'-monoxime & ( $10 \mathrm{uM})$ & +++ & +++ & +++ & +++ & ++ & ++ & $\begin{array}{l}\text { CDKI(I80), CDK2(250), } \\
\text { CDK4(3330), CDK5(I00) }\end{array}$ \\
\hline & $\begin{array}{l}\text { Indirubin-3'-monoxime-5'- } \\
\text { lodo }\end{array}$ & ( $10 \mathrm{uM})$ & +++ & +++ & +++ & +++ & ++ & ++ & CDKI (25), CDK5(20) \\
\hline & 9-Cyanopaullone & (10 uM) & ++++ & + & - & - & - & - & CDKI(24), CDK5(44) \\
\hline & Aloisine A & ( 10 uM) & +++ & + & - & - & - & - & $\begin{array}{l}\text { CDKI }(150), \text { CDK2(I20), } \\
\text { CDK5(200) }\end{array}$ \\
\hline & Compound 52 & (10 uM) & +++ & + & - & - & - & - & CDKI $(340)$ \\
\hline & Flavopiridol & (0.I uM) & ++ & + & - & - & - & - & $\operatorname{CDK} 9(50)$ \\
\hline \multirow[t]{16}{*}{ Moderate } & r-Roscovitine & $(10 \mathrm{uM})$ & ++ & - & - & - & - & - & $\begin{array}{l}\text { CDKI }(650), \text { CDK2(700), } \\
\text { CDK5(I60), CDK7(500) }\end{array}$ \\
\hline & Bohemine & (10 uM) & ++ & - & - & - & - & - & CDKI $(1000)$ \\
\hline & s-Roscovitine & (10 uM) & + & - & - & - & - & - & $\begin{array}{l}\text { CDKI (650), CDK2(700), } \\
\text { CDK5(I60), CDK7(500) }\end{array}$ \\
\hline & WHI-PI80 & (10 uM) & + & N/A & N/A & - & N/A & N/A & CDK2(1000) \\
\hline & Kenpaullone & ( $10 \mathrm{uM})$ & + & - & - & - & - & - & $\begin{array}{l}\text { CDKI }(400), \text { CDK2(680), } \\
\text { CDK5(850) }\end{array}$ \\
\hline & 2,6-Diaminopurine & (10 uM) & - & + & - & - & - & - & \\
\hline & Flavone & (10 uM) & + & - & - & - & - & - & $\begin{array}{l}\text { CDKI }(300), \text { CDK2(100), } \\
\text { CDK4(400), CDK7(300) }\end{array}$ \\
\hline & Alsterpaullone & ( $10 \mathrm{uM})$ & ++++ & ++ & +++ & + & ++ & ++ & $\begin{array}{l}\text { CDKI }(35), \text { CDK2(I5), } \\
\text { CDK5(40) }\end{array}$ \\
\hline & CGP 745I4A & ( $10 \mathrm{uM})$ & ++++ & ++ & +++ & + & ++ & ++ & CDKI $(25)$ \\
\hline & BAY II-7085 & (10 uM) & + & ++++ & +++ & N/A & ++++ & ++++ & \\
\hline & BAY II-7082 & ( $10 \mathrm{uM})$ & + & ++++ & +++ & N/A & ++++ & ++++ & $\mathrm{IkBa}(10000)$ \\
\hline & CAPE & (10 uM) & + & +++ & - & N/A & ++++ & ++++ & \\
\hline & Diethylmaleate & (10 uM) & + & +++ & - & N/A & ++++ & ++++ & \\
\hline & Parthenolide & (10 uM) & + & +++ & +++ & N/A & ++++ & ++++ & \\
\hline & $\begin{array}{l}\text { Pyrrolidinedithiocarbamic } \\
\text { acid }\end{array}$ & ( $10 \mathrm{uM})$ & - & +++ & +++ & N/A & ++++ & ++++ & \\
\hline & Wedelolactone & ( $10 \mathrm{uM})$ & + & ++ & - & N/A & ++ & ++ & \\
\hline \multirow[t]{17}{*}{ Poor } & 6-Benzyloxypurine & $(10 u M)$ & - & - & - & - & - & - & \\
\hline & 5-amino alicylic acid & ( $10 \mathrm{uM})$ & - & - & - & N/A & - & - & \\
\hline & 2,6-Dichloropurine & (10 uM) & - & - & - & - & - & - & \\
\hline & 6-Dimethylaminopurine & (10 uM) & - & - & - & - & - & - & CDC \\
\hline & $\begin{array}{l}\text { Indirubin-3'-monoxime-5'- } \\
\text { sulphonic acid }\end{array}$ & ( $10 \mathrm{uM})$ & - & - & - & - & - & - & CDKI(5), CDK5(7) \\
\hline & Iso-olomoucine & ( $10 \mathrm{uM})$ & - & - & - & - & - & - & $\begin{array}{l}\text { CDKI }(>500,000) \\
\text { CDK } 4,5(>1,000,000)\end{array}$ \\
\hline & N-6-( $\Delta 2$-Isopentyl)-adenine & (10 uM) & - & - & - & - & - & - & CDKI,2,5(>50,000) \\
\hline & Olomoucine & $(10 u M)$ & - & - & - & - & - & - & CDKI,2(7000), CDK5(3000) \\
\hline & Olomoucine, N9-isopropyl & $(10 u M)$ & - & - & - & - & - & - & CDKI $(2000)$ \\
\hline & $S C-514$ & (10 uM) & - & - & - & - & - & - & IKK-I (>200), IKK-2(I I.2) \\
\hline & QNZ & (10 uM) & - & - & - & N/A & ++ & + & \\
\hline & $\begin{array}{l}* \text { positive sign indicates level } \\
\text { of cell inhibition }\end{array}$ & & Inhibition & Percentage & & & & & \\
\hline & $\begin{array}{l}\text { ** negative sign indicates no } \\
\text { cell inhibition }\end{array}$ & & - & $1-5 \%$ & & & & & \\
\hline & & & + & $25 \%$ & & & & & \\
\hline & & & ++ & $50 \%$ & & & & & \\
\hline & & & +++ & $75 \%$ & & & & & \\
\hline & & & ++++ & $90 \%$ & & & & & \\
\hline
\end{tabular}


A)

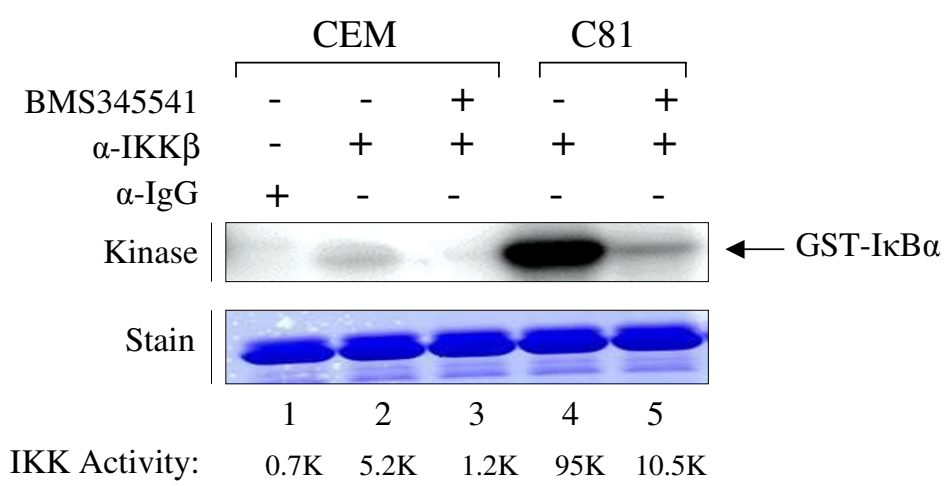

B)

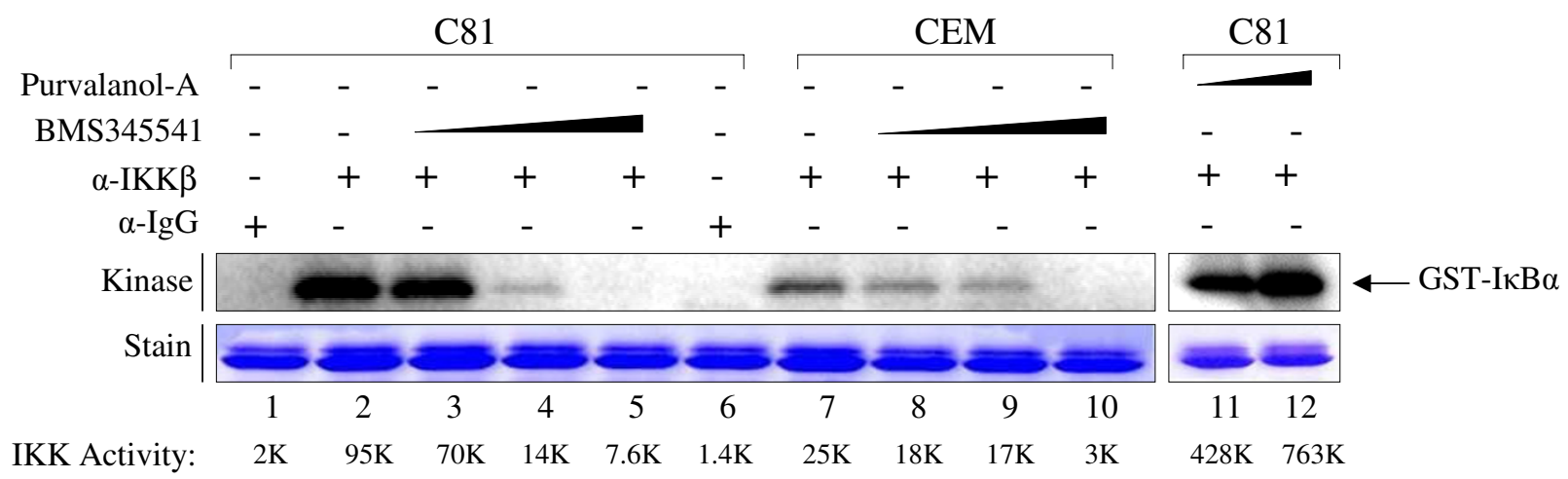

Figure I

BMS-34554 I inhibition of IKK $\beta$ in HTLV-I infected cell. A) BMS-34554I reduced IKK $\beta$ activity in C8I66 cells. Equal amount (I mg) of cytoplasmic proteins was immunoprecipitated with anti-IKK $\beta$ antibody and mixed with I $\mu$ M BMS-34554I. The IKK $\beta$ activities were examined by in vitro kinase assay using GST-IKB $\alpha$ as a substrate. The $\left[\gamma-{ }^{32} \mathrm{P}\right]$-labeled IKB- $\alpha$ protein was visualized by autoradiography. The IKK $\beta$ activities were quantitated by ImageQuant software. The bottom panel shows a commassie blue staining of GST-IKB $\alpha$ to show equal amount of substrate in each reaction. B) BMS-34554I inhibited IKK $\beta$ activity in C8I66 cells in dose-dependent manner; however, Purvalanol A had no effect on IKK $\beta$. Kinase assay were performed as described above using $0.0 \mathrm{I}, 0 . \mathrm{I}$, and I $\mu \mathrm{M}$ of BMS-34554I and I, I0 $\mu \mathrm{M}$ of Purvalanol A. The stained gel below is a representative of the kinase reaction.

1 cells much more efficiently as compared to uninfected cells.

\section{Effect of BMS-34554I on inhibition of $I_{\kappa} B$ and $p 65$ phosphorylation in vivo}

We subsequently asked if I $\mathrm{B}$ or p65 levels could be altered in drug treated infected and uninfected cells. We therefore Western blotted our drug treated cells with anti-

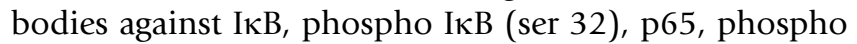
p65 (ser 536), p50, p52, Tax and actin. Both ser 32 of IкB and ser 536 of p65 are phosphorylated by IKK $\beta$ in vivo. Results of such an experiment are shown in Figure 3 where $\mathrm{I} \kappa \mathrm{B}$ levels essentially stayed the same in all three cell lines except for a drop in C8166 cells at $5.0 \mu \mathrm{M}$. We have previously observed that cells, irrespective of infection, treated with BMS-345541 at higher does (i.e., $10.0 \mu \mathrm{M}$ ) are toxic and show non-specific activation of apoptotic machinery (data not shown). There was also no change in levels of p65 although a slight increase in C8166 cells was observed at higher concentrations. A more interesting set of results were observed with phosphor- $\mathrm{I} \kappa \mathrm{B}$ and phosphor-p65 blots. MT-2 cells treated with BMS-345541 showed a reduction of both phosphor-I $\kappa \mathrm{B}$ and phosphorp65 levels at $0.5 \mu \mathrm{M}$. Similar results were also seen in C8166 cells. Very little phosphor-I $\kappa \mathrm{B}$ and phosphor-p65 were observed in CEM cells (or other control Jurkat cells, 
A)

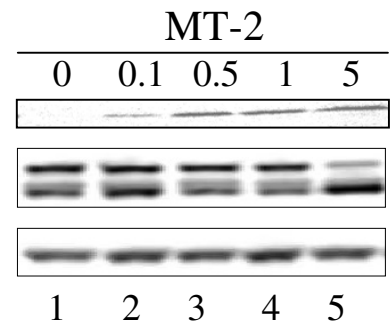

B)

MT-2
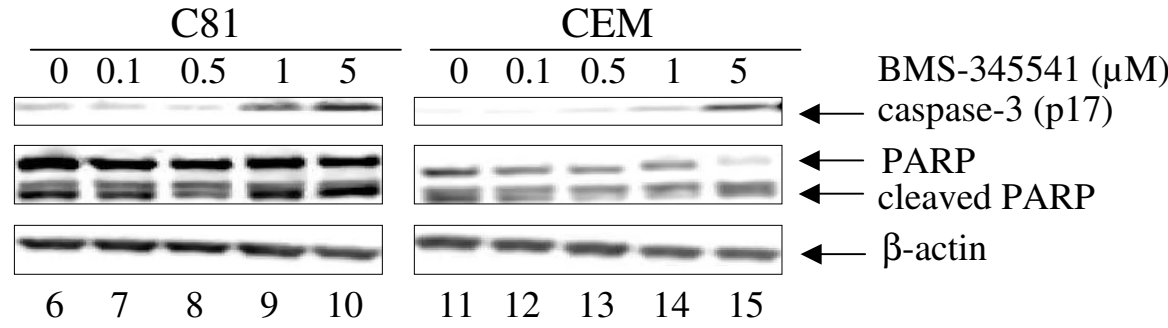

No Treatment

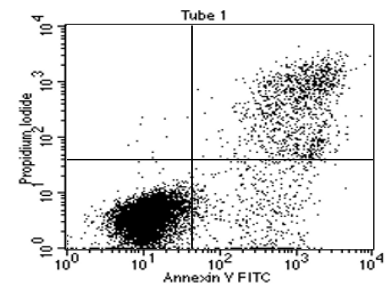

$\underline{\operatorname{BMS}-345541(1 \mu \mathrm{M})}$

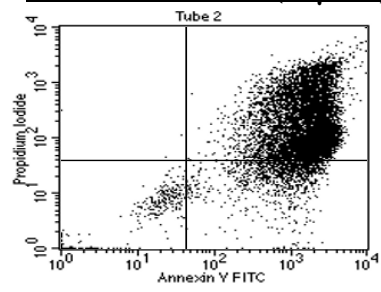

C81
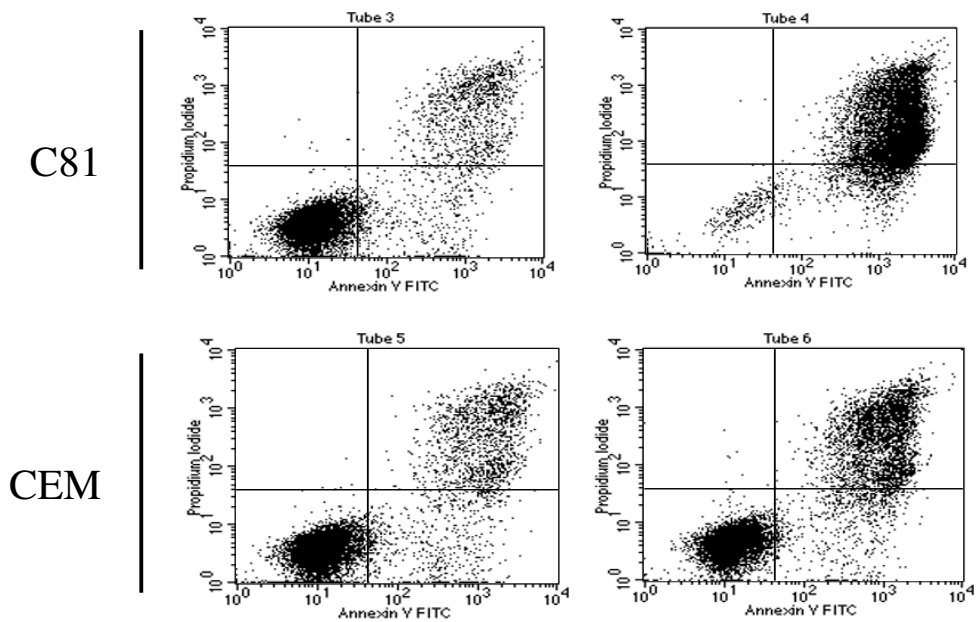

\section{Figure 2}

BMS-34554I induction of apoptosis in C8 I66. A) BMS-34554I induced caspase-3 and PARP cleavage C8I66. MT-2, C8I 66, and CEM cells were treated with BMS-34554I at $0 . \mathrm{I}, 0.5$, I, and $5 \mu \mathrm{M}$ for $48 \mathrm{hr}$. Total cell extracts were subjected to Western blot analysis for caspase- 3 and PARP. $\beta$-actin Western blot was used as internal control. The results of caspase-3 were quantitated and normalized with $\beta$-actin. The ratio of c/un PARP was calculated by dividing cleaved PARP to un-cleaved PARP (data not shown). B) Detection of apoptosis through annexin $\mathrm{V}$ and PI staining. Cells were washed three times in PBS and re-suspended in binding buffer, stained with annexin V-FITC and PI for 15 minutes at room temperature. Analysis was performed on a BD FacsCalibur flow cytometer.

data not shown). P50, p52 levels were unchanged with various drug concentrations and Tax levels were not decreased at 0.5 or $1.0 \mu \mathrm{M}$ concentration of the drug. No changes were seen in the actin levels in any of the treated cells. Collectively, these results indicate that inhibition of IKK $\beta$ in HTLV-1 infected cells by BMS-345541 affects phosphorylation of both IкB and p 65 molecules, both of which may be the hallmarks of NF- $\mathrm{KB}$ activation in HTLV1 infected cells.
Inhibition of cyclin/CDK complexes by Purvalanol A

We have previously shown that cyclin E/CDK2 kinase activity is de-regulated in HTLV-1 infected cells and these cells are especially susceptible to Purvalanol A treatment [62]. Moreover, Purvalanol A, which is a purine analog that competes with the ATP binding site in CDKs, has been shown to inhibit cyclin E/CDK2 and cyclin A/CDK2 kinase activities with an $\mathrm{IC}_{50}$ of 0.035 and $0.07 \mu \mathrm{M}$, respectively [74-77]. We therefore treated both infected 
and uninfected cells for 48 hours with Purvalanol A and Western blotted for caspase-3 and PARP molecules. Results in Figure 4A show that the caspase- 3 p 17 molecule was present in infected cells treated with 0.1 and $0.5 \mu \mathrm{M}$ of Purvalanol A (lanes 3 and 7). This was important since Purvalanol A did not significantly activate caspase-3 in CEM (lanes 11-15) or Jurkat cells (data not shown). There were no changes in actin (bottom panel), cyclin E, or cyclin A expression levels when treated with Purvalanol A (Panel B). Therefore Purvalanol A treatment induces caspase- 3 activation in HTLV-1 infected, and not in uninfected cells. This is consistent with our previous results where Purvalanol A treatment of infected cells inhibited cyclin E/CDK2 complex activity in HTLV-1 infected cells, inhibited transcription of the LTR promoter and promoted apoptosis [62]. Along these lines, we also assayed for changes in cell cycle progression and apoptosis in these cells using FACS analysis. Results in Figure 5 show the titration of Purvalanol A for all three cell types. Interestingly, significant apoptosis appeared in infected cells treated at 1.0 and $5.0 \mu \mathrm{M}$ concentrations.

\section{Inhibition of viral replication using both drugs}

We next decided to use both drugs in a viral replication assay in MT-2 cells. MT-2 cells normally produce low levels of infectious HTLV-1 virions that could be detected in the supernatant using p19 gag ELISA. However, treatment of these cells with TNF can produce at least 1-2 log more virus that is shed into the supernatant. We therefore treated MT- 2 cells with TNF for 2 hours and subsequently treated them with BMS-345541 alone $(0.1 \mu \mathrm{M})$, Purvalanol A alone $(0.5 \mu \mathrm{M})$, or a combination of both drugs. Results in Figure 6A show that, as compared to untreated cells, TNF treatment induced high amounts of p19 gag in the supernatant (lanes 1 and 2). Both drugs alone reduced p19 levels to some degree however; the best inhibition was seen with the combination of both drugs where NF$\kappa \mathrm{B}$ and CDK pathways were targeted in these cells. Similar results were also obtained in 293 cells transfected with ACH full-length infectious clone, where a combination of both drugs inhibited p19 expression as compared to when treated with one drug alone (Panel $\mathrm{B}$ ). Collectively, these results imply that low concentrations of NF- $\mathrm{BB}$ and CDK inhibitors that normally do not cause cell death in uninfected cells are effective inhibitors against HTLV-1 infected cells.

\section{Discussion}

In contrast with the latest progress in the understanding of HTLV-1 infection, its pathogenesis and its mechanism of action, more progress in developing therapies for these infected cells is needed. There has been only very limited improvement in the prognosis of virally associated diseases (ATL and HAM/TSP) during the past several years. However few well established pathways including NF-кB and cell cycle progression have been shown to be tightly regulated in HTLV-1 and Tax expressing cells and therefore providing viable targets for treatment $[51,78,79]$. Along these lines, we searched various inhibitors targeting these two pathways using published literature and our own search using few small libraries of compounds tested here. We selected inhibitors with low-high $\mathrm{IC}_{50}$ in various cell types and identified their cell growth inhibition efficiencies in HTLV-1 infected and uninfected cells. Results in Table 1 clearly show that there are various compounds that specifically target HTLV-1 (and Tax) producing cells. Many of these compounds have known targets and more importantly are not inhibitors of other viruses including HIV-1 (more then 78\% have different IC50 in HIV-1 infected cells, data not shown). Furthermore, the inhibitors in high selectivity group showed higher inhibition efficiency in MT-2 cells which normally produces some level of full length infectious HTLV-1 particles in the absence of any inducer. Therefore, it is interesting to note that these inhibitors not only had specificity to inhibit Tax expressing cells but also showed better growth inhibition toward infected cells that produce high titer virus.

In high selectivity group, BMS-345541 and Purvalanol A demonstrated the best selectivity to block growth of all HTLV-1 infected cells and no blockage to control cells in these concentrations (Table 1). Indirubin-3'-monoxime and 5'-Indo-indirubin-3'-monoxime inhibited growth of infected cells and also inhibited control cells. 9-Cyanopaullone, Aloisine A, Compound 52, and Flavopiridol showed less growth inhibition in inhibiting two out of four infected cell lines. Consequently, we decided to focus and study the mechanism of BMS-345541 and Purvalanol A inhibition in HTLV-1 infected cells.

In this study, we showed that BMS-345541 inhibited IKK $\beta$ kinase activity from HTLV-1 infected cell. IKK $\beta$ subunits associating with canonical pathway is responsible for activating NF- $\kappa B$ by phosphorylating I $\kappa \mathrm{B} \alpha$. Furthermore, BMS-345541 induced higher level of apoptosis in C8166 and other cells (data not shown). Therefore, we speculated that BMS-345541 suppressed IKK $\beta$ and further blocked NF- $\kappa B$ signaling pathway, the survival pathway, to induce apoptosis. As illustrated in our model, in the presence of BMS-345541, the level of unphosphorylated $\mathrm{I} \kappa \mathrm{B} \alpha$ is expected to increase and keep NF- $\mathrm{KB}$ dimmers in cytoplasm and block its transcriptional ability (Figure 7). In addition, IKK $\beta$ activity in C8166 was dramatically down-regulated by BMS-345541 with an $\mathrm{IC}_{50}$ at $0.05 \mu \mathrm{M}$ in a dose-dependent manner, whereas the $\mathrm{IC}_{50}$ in CEM cell was at $0.5 \mu \mathrm{M}$. The HTLV- 1 infected cell was at least 10 times more sensitive to BMS-345541 than control cells. This critical difference is thought to be the related to the NF- $\kappa B$ pathway in HTLV-1 infected cell. NF- $\kappa B$ is tightly controlled in normal T-cells; however, HTLV-1 control of 

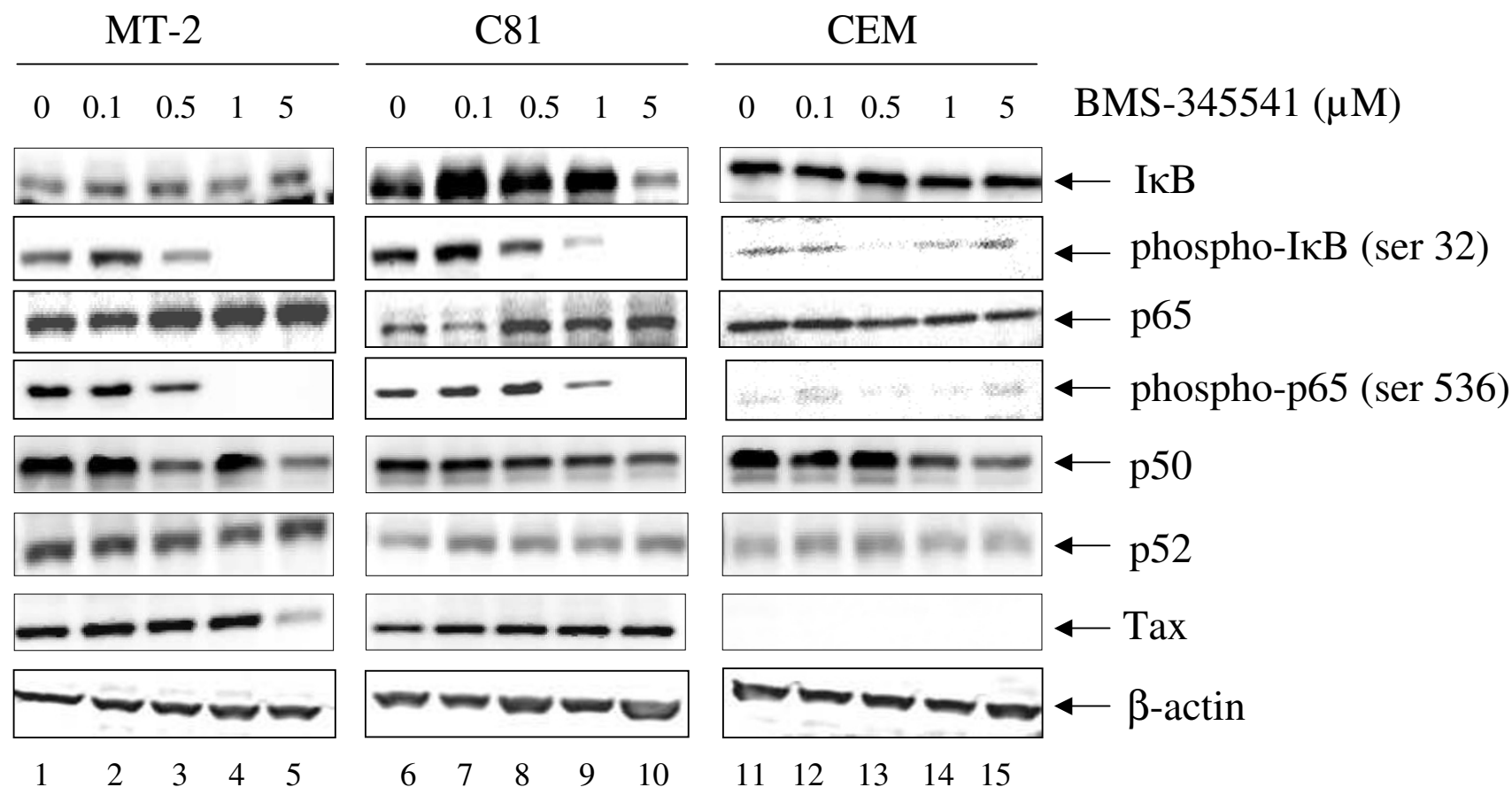

Figure 3

Effect of BMS-34554I on inhibition of $\mathrm{I} \kappa \mathrm{B}$ and $\mathrm{p} 65$ phosphorylation in vivo. MT-2, C8I66, and CEM cells were treated with BMS-34554I at $0.1,0.5$, I, and $5 \mu \mathrm{M}$ for $48 \mathrm{hr}$. Total cell extracts were collected and subjected to Western blot

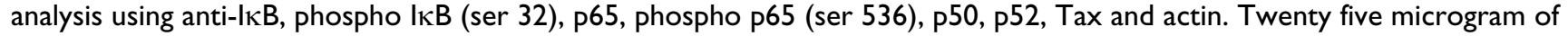
each extract was used to separate on a 4-20\% SDS/PAGE. Levels of total I $\mathrm{kB}$ and $\mathrm{p} 65$ did not change between cell types, however there was a dramatic increase of phosphor-IKB and phosphor-p65 in HTLV-I infected cells and their suppression by BMS34554 I which inhibits IKK $\beta$ activity in vivo.

the host cells depends on constitutively activated NF- $\mathrm{B}$ for quelling apoptosis. Inhibition of NF- $\kappa \mathrm{B}$ in HTLV-1 infected cell is tantamount to blocking the significant survival pathway.

In infected patients, dysregulation of cell cycle regulatory proteins is considered to promote cell cycle progression and overcome cellular checkpoints. Tax activates the expression of cyclin D2, cyclin E, CDK2, and CDK4 and the kinase activity of cyclin E/CDK2 which accelerates $\mathrm{G}_{1}$ $/ S$ transition and promotes passage through the restriction point immediately [2,51]. Furthermore, it has been shown that other viruses such as Epstein-Barr virus (EBV) also accelerates viral replication by activating S-phase promoting CDKs such as cyclin E/CDK2 and cyclin A/CDK2 and consequently accumulating hyperphosphorylated non-functional $\mathrm{Rb}$ [80]. In this study, we identified the CDK inhibitor with the best specificity to ATL cells to be Purvalanol A (Table 1). This drug showed induction of apoptosis as evident from increased caspase 3 activity. Purvalanol A was previously shown by us to effect the in vivo transcription of HTLV-1 promoter and inhibit viral replication and cell growth by MTT assay [81].
An important advance in the treatment of ATL was reported in two preliminary phase II studies with the combination of an anti-retroviral agent zidovudine (AZT) and interferon- $\alpha$ (IFN- $\alpha$ ) in previously untreated, as well as in relapsed acute ATL and ATL lymphoma [82-84]. The phase II study showed a high response rate which has never been previously reached with any chemotherapy regimen [85]. Dual drugs treatment with arsenic trioxide and IFN- $\alpha$ in ATL patients also had significant inhibition and specificity in phase II trial [86]. Arsenic trioxide tar-

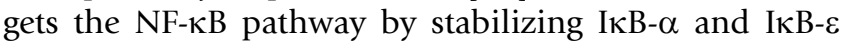
[44]. The combination drug treatment induced proteasomal degradation of Tax and resulted in the reversal of NF$\kappa \mathrm{B}$ transcription factor activation [87]. Therefore, we utilized a combined treatment of HTLV-1 infected cells with BMS-345541 and Purvalanol A. We performed similar experiments in MT-2 cells that can produce high amounts of virus after TNF treatment. Interestingly, combination of both drugs at low concentration inhibited viral production without having any toxic effects (in either infected or uninfected cells). Although it should also be noted that our results don't show if Purvalanol A and BMS-345541 prevent cells from HTLV-1 infection and whether possible 
A)
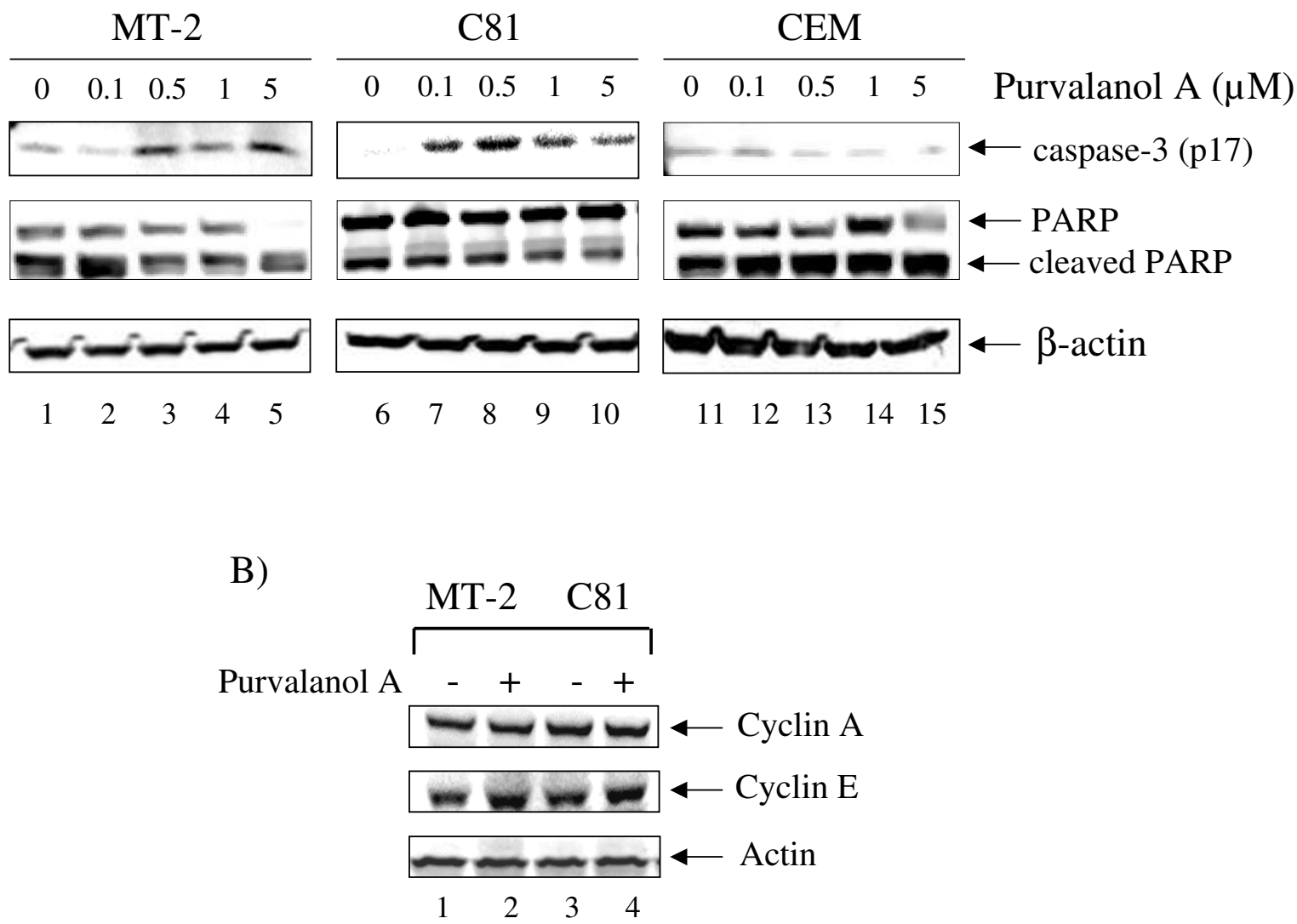

\section{Figure 4}

Purvalanol A induction of apoptosis in MT-2. A) Purvalanol A induced caspase-3 and PARP cleavage in MT-2 and C8I66 cells. MT-2, C8I66, and CEM were treated with Purvalanol A at various $0.1,0.5$, I, and $5 \mu M$ for 48 hr. After 48 hr of treatment, total cell extracts were collected and subjected to Western blot analysis of caspase- 3 and PARP. Westeron blot of $\beta$ actin was used as an internal control. B) Twenty five microgram of each Purvalanol A treated (5 $\mu \mathrm{M}$ for $48 \mathrm{hr}$ ) extracts from both MT-2 and C8166 cells were also used for western blot against cyclin A, E and actin.

receptor(s) of HTLV-1 infection are altered when using these drugs. Collectively, combination of two drugs that can inhibit both NF- $\mathrm{B}$ and CDK machineries in HTLV-1 "hyper-active" cells seem to be a viable option in inhibiting infection. Future experiments are in progress to develop second and third generation drugs, as well as their effect in fresh ATL samples and inhibition in mouse models.

\section{Conclusion}

Recently, unique therapeutic approaches targeting molecules and/or mechanisms involved in the pathogenesis of HTLV-1 have been explored, and some have produced encouraging results that might lead to breakthrough therapies. In this study, we have demonstrated that two drugs (BMS-345541 and Purvalanol A) out of thirty-five drugs studied that target NF- $\kappa$ B or CDK pathways had the best specificity in inhibiting the growth of HTLV-1 infected but not uninfected cells. The effect of BMS-345541 is through the inhibition of IKK $\beta$ kinase activity resulting in dephosphorylation of $\mathrm{I} \kappa \mathrm{B} \alpha$ and inactivation of NF- $\mathrm{B}$ pathway. The specificity of BMS-345541 with $\mathrm{IC}_{50}$ of $50 \mathrm{nM}$ in HTLV-1 infected cell compared to $\mathrm{IC}_{50}$ of $500 \mathrm{nM}$ in uninfected cell therefore renders the infected cells 10 times more sensitive to the drug than uninfected cell. The other inhibitor, Purvalanol A induced higher level of inhibition in MT-2 cells and the mechanism was previously shown by us to be associated with inhibition of functional cyclin E/CDK2 complexes. Combination of these two inhibitors induced even higher level of p19 Gag expression in infected cells. Therefore, treatment of HTLV-1 infected cells with either BMS-345541, Purvalanol A or a combination of these two drugs hold promising leads in treatment of infected cells. 


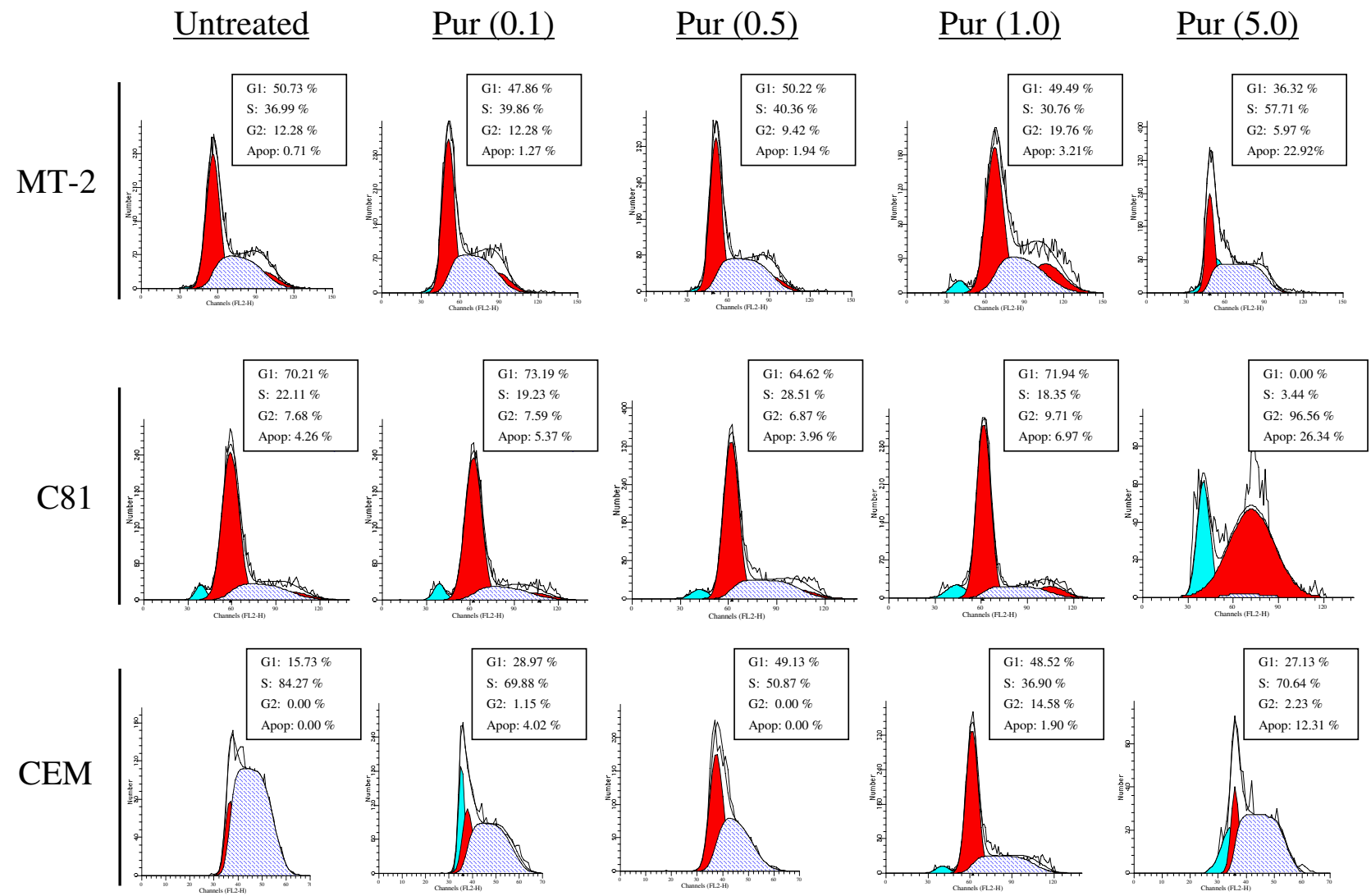

Figure 5

Cell cycle analysis of cells treated with or without drugs. For fluorescence-activated cell sorting (FACS) analysis, both untreated and Purvalanol A treated CEM, MT-2 and C8I66 cells $(0.1-5.0 \mu \mathrm{M})$ were stained with a mixture of propidium iodide buffer followed by cell sorting analysis. The acquired FACS data were analyzed by ModFit LT software (Verity Software House, Inc.).

\section{Methods}

\section{Cell lines and reagents}

MT-2, MT-4, C8166, and C10/MJ were all obtained from NIH AIDS Research \& Reference Reagent Program. They are all HTLV-1 infected cell lines and some including C8166 contain defective viruses but still express Tax. MT2 cells carry multiple copies of the HTLV-1 cosmopolitan subtype and normally produce some full length infectious HTLV-1 particles in the absence of any inducer [157]. MT4 cells are established from the human T cells isolated from a patient with adult T-cell leukemia. CEM and Jurkat cells are the uninfected control T lymphocyte cell lines. All cell lines were cultured at $37^{\circ} \mathrm{C}$ up to $1 \times 10^{5}$ cells per ml in RPMI 1640 medium containing fetal bovine serum $(10 \%)$, streptomycin, penicillin antibiotics $(1 \%)$ and LGlutamine (1\%) (Gibco/BRL). The CDK inhibitors used were: Aloisine A (270-385-M001), Alsterpaullone (270275-M001), Bohemine (270-390-M001), CGP74514A (270-391-M001), Compound 52 (270-248-M001), 9- cyanopaullone (270-282-M001), 6-dimethylaminopurine (480-050-M100), indirubin-3'-monoxime (270-271M001), 5-iodo-indirubin-3'-monoxime (270-424-M001), N-6-( $\Delta 2$-Isopentenyl)-adenine (350-034-M100), Kenpaullone (270-274-M001), Olomoucine (350-013M005), N9-isopropylolomoucine (270-397-M001), Purvalanol A (270-246-M001), (R)-Roscovitine (350-251M001), (S)-Roscovitine (350-293-M001) were purchased from Alexis Inc. and 6-benzyloxypurine (387606), 2,6diaminopurine (247847), 2,6-dichloropurine (D73103), Flavone (F2003) were purchase from Sigma-aldrich Inc. Indirubin-3'-monoxime-5-sulfonic acid (402088), isoolomoucine (495622), WHI-P180 (681500) were purchased from Calbiochem Inc. The CDK inhibitor, flavopiridol was a kind gift from Dr. Ajit Kumar at the GWUMC. The NF-кB inhibitors included BMS-345541 (401480), SC-514 (401479) were purchased from Calbiochem Inc. and 5-Aminosalicylic acid (430-110-G005), BAY 11-7082 (270-219-M010), BAY 11-7085 (270-220- 
A)

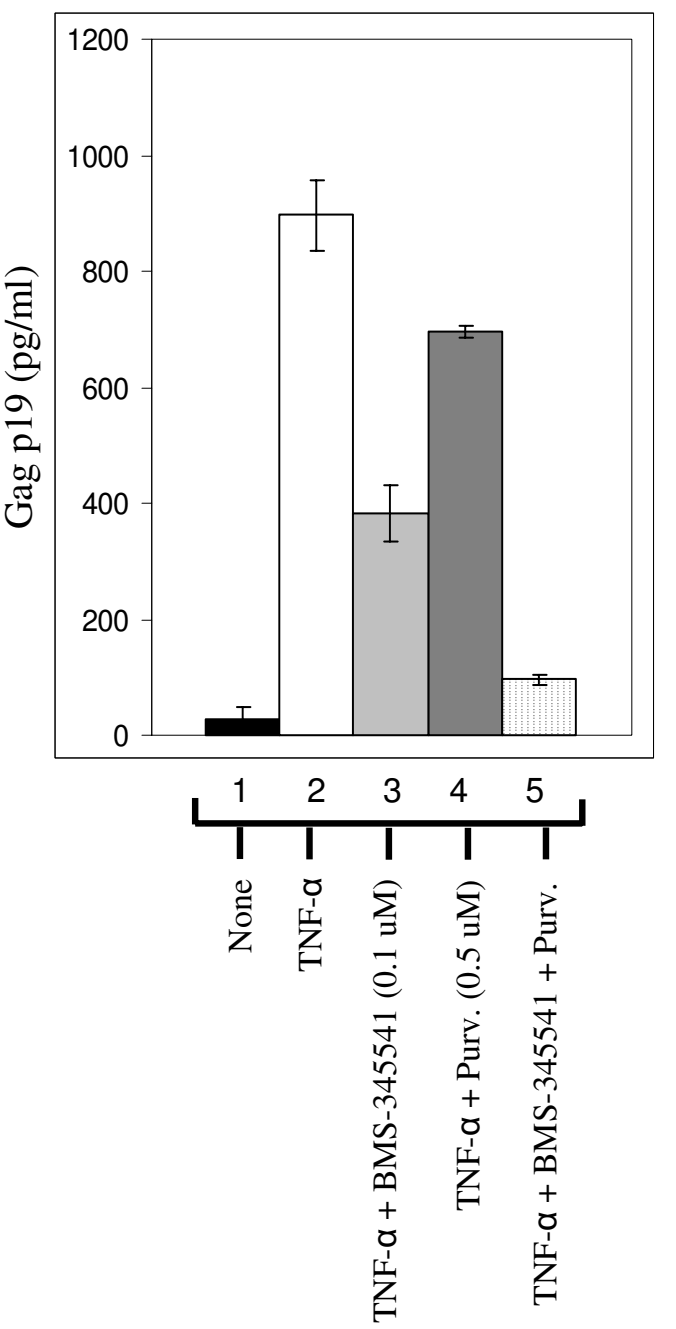

B)

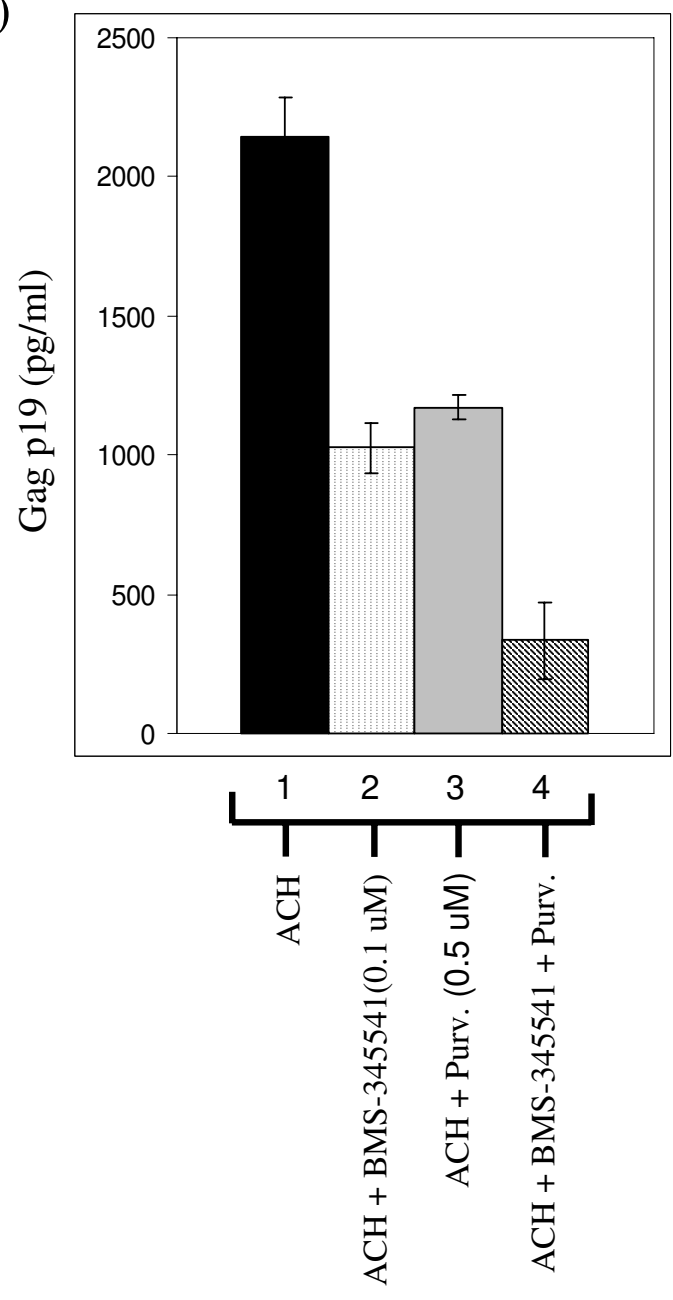

\section{Figure 6}

Double drugs treatment results in lower 19 Gag levels in HTLV-I infected cells. A) MT-2 cells (HTLV-I infected) were treated with TNF- $\alpha(10 \mathrm{ng} / \mathrm{ml})$ for $2 \mathrm{~h}$, washed, and subsequently treated with a specific NF-kB or CDK inhibitor. Activated cells were subsequently treated them with BMS-34554I alone $(0.1 \mu \mathrm{M})$, Purvalanol A alone $(0.5 \mu \mathrm{M})$, or a combination of both drugs. Samples were collected after 7 days and used for detection of p 19 Gag using ELISA. B) Log phase 293 cells were transfected with ACH.pcTax (wild type HTLV-I clone, generous gift of Dr. Lee Ratner, Washington University) using electroporation method. After transfection, the cells were cultured in complete medium and culture supernatants were collected at 4 days post-transfection, and virus particle production was monitored by pI 9 ELISA. Drug treatments (as in panle A) were 6 hrs after transfection of the 293 cells for a total of $150 \mathrm{hrs}$.

M010), caffeic acid phenylethyl ester (270-244-M010), diethylmaleate (280-017-G005), Parthenolide (350-258M025), pyrrolidinedithiocarbamic acid (400-002-G005) were purchased from Alexis Inc. and QNZ (6-amino-4-(4phenoxyphenylethylamino)quinazoline

(EI-352), Wedelolactone (EI-316) were purchased from Biomol Inc. All inhibitors were prepared in $10 \mathrm{mM}$ stock solution. 2,6Dichloropurine and diethylmaleate were dissolved in ethanol; Flavone was dissolved in acetone; Flavopiridol and pyrrolidinedithiocarbamic acid were dissolved in water; 5-aminosalicylic acid was dissolved in hydrochloric acid. The other twenty-nine inhibitors were all dissolved in DMSO.

\section{Drugs screening and cell counting}

HTLV-1 infected cells and uninfected cells were treated with thirty-five inhibitors at four concentrations including $0.01,0.1,1$, and $10 \mu \mathrm{M}$. Forty-eight hours after treatment, 

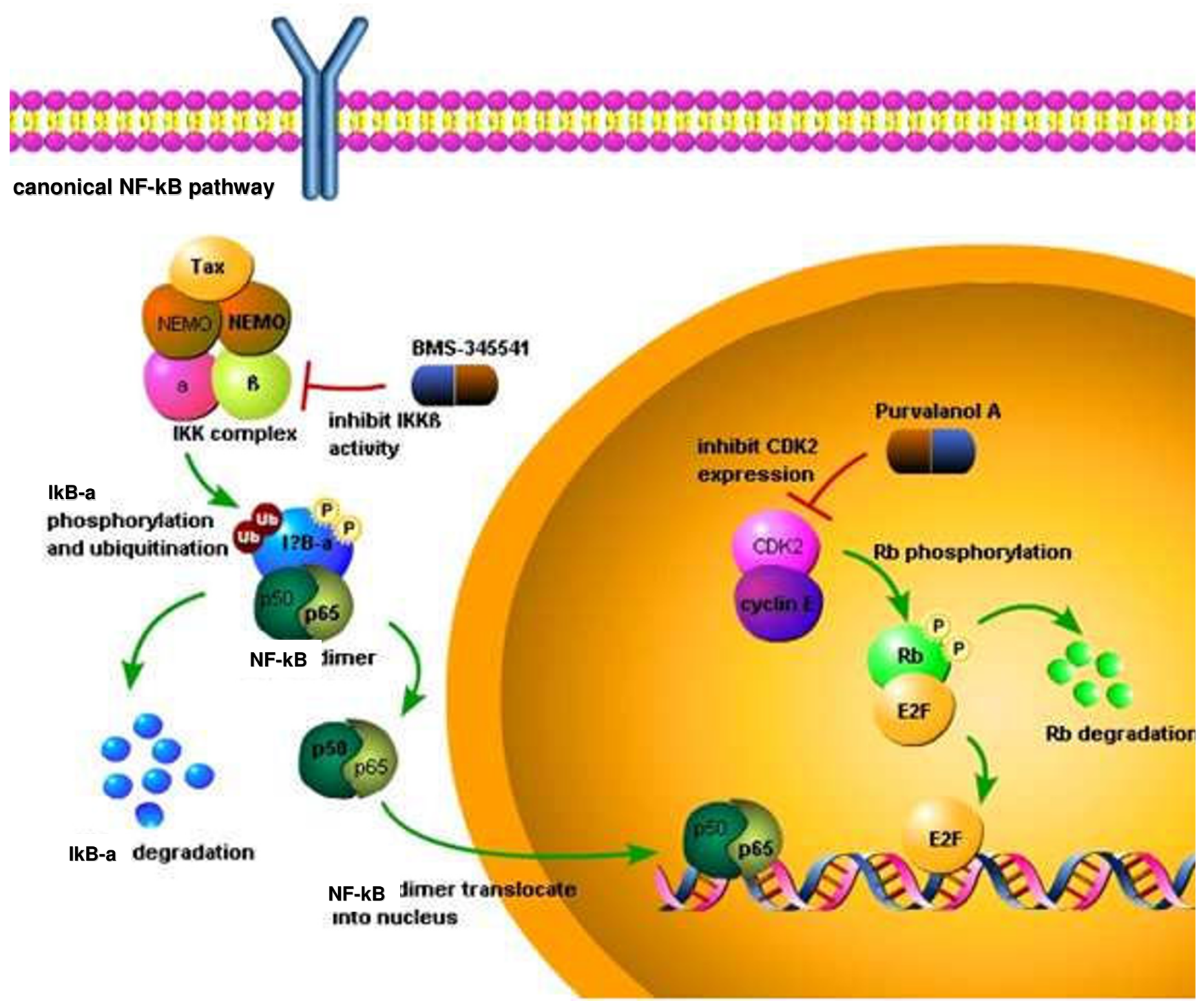

\section{Figure 7}

Inhibition mechanism of BMS-34554 I and Purvalanol A in HTLV-I infected cells results in blocking canonical NF- $K B$ signaling pathway and cell cycle progression. In the absence of drug, hyperactive IKK complex phosphorylates IKB- $\alpha$ resulting in I $\mathrm{KB}-\alpha$ degradation and $p 65 / \mathrm{p} 50$ translocation. The genes transcribed by $p 65 / 50$ include anti-apoptotic genes which are responsible for survival of virus infected cells. In the presence of BMS-34554I, the activity of IKK complex is inhibited which results in decreased IKB- $\alpha$ phosphorylation, therefore $p 65 / p 50$ are kept in cytoplasm. Hence, the expression of antiapoptotic proteins are decreased which make HTLV-I infected cells more susceptible and sensitive to the action of the drug. Without drugs, cyclin E/CDK2 phosphorylates $\mathrm{Rb}$ and induces $\mathrm{Rb}$ degradation. The free $\mathrm{E} 2 \mathrm{~F}$ then transcribes genes which are necessary for GI/S transition. However, Purvalanol A inhibits CDK2 (a non-essential protein in the life cycle of a cell) activity, as previously shown by us, which results in decreased $\mathrm{Rb}$ phsophorylation and inactivated E2F. Therefore, the infected cells may be blocked at the $G_{1}$ checkpoint and simultaneously have lower viral expression.

cytotoxicity was primarily determined by the color of media and cell viability by trypan blue exclusion. Cells were counted for the number of living cells every $24-48$ hrs. Subsequent focusing experiments used flow data to check for viability and apoptosis.

\section{Cytoplasmic extracts}

Cytoplasmic extracts were prepared according to the following procedure. Briefly, cells were collected and washed with PBS once and then once with $80 \mu$ lof ice-cold buffer A (Tris-HCl (pH 7.4, $10 \mathrm{mM}), \mathrm{MgCl}_{2}(1.5 \mathrm{mM}), \mathrm{KCl}(10$ $\mathrm{mM})$, DTT $(1 \mathrm{mM}), 0.4 \%$ NP-40, phenylmethylsulfonyl 
fluoride $(1 \mathrm{mM})$, aprotinin $(10 \mu \mathrm{g} / \mathrm{ml})$, pepstatin $(1 \mu \mathrm{M})$, $\mathrm{NaF}(50 \mathrm{mM})$, and $\left.\mathrm{Na}_{3} \mathrm{VO}_{4}(1 \mathrm{mM})\right)$. Cells were lysed in $80 \mu \mathrm{l}$ of buffer A by gently passing the cell suspension through a 28-gauge needle. The cytoplasmic extracts were collected by pelleting for $8 \mathrm{sec}$ in an Eppendorf microcentrifuge and the supernatant was collected. The protein concentration for each preparation was determined with a Bio-Rad protein assay kit (Bio-Rad Laboratories, Hercules, CA, USA).

\section{Immunoprecipitation and in vitro kinase assay}

Reaction mixtures $(24 \mu \mathrm{l})$ contained (final concentrations) $40 \mathrm{mM} \quad \beta$-glycerophosphate, $\mathrm{pH} 7.4,7.5 \mathrm{mM}$ $\mathrm{MgCl} 2,7.5 \mathrm{mM}$ EGTA, 5\% glycerol, [ $\gamma^{32}$-P]ATP $(0.2 \mathrm{mM}$, $1 \mu \mathrm{Ci}), 50 \mathrm{mM} \mathrm{NaF}, 1 \mathrm{mM}$ orthovanadate, and $0.1 \%(\mathrm{v} /$ v) $\beta$-mercaptoethanol. Phosphorylation reactions were performed with $2 \mathrm{mg}$ of cytoplasmic extract immunoprecipitated with appropriate antibody and washed in lysis buffer containing $50 \mathrm{mM}$ Tris- $\mathrm{HCl}(\mathrm{pH} 7.5), 120 \mathrm{mM}$ $\mathrm{NaCl}, 5 \mathrm{mM}$ EDTA, $50 \mathrm{mM} \mathrm{NaF}, 0.2 \mathrm{mM} \mathrm{Na}_{3} \mathrm{VO}_{4}, 1 \mathrm{mM}$ DTT, $0.5 \%$ NP-40 and protease inhibitors (Protease inhibitor cocktail tablets, Boehringer Mannheim, one tablet per $50 \mathrm{ml}$ ) or with $1 \mu \mathrm{g}$ of purified recombinant GST-I $\kappa \mathrm{B} \alpha$ at $37^{\circ} \mathrm{C}$ for 1 hour. Reactions were stopped by adding 1 volume of Laemmli sample buffer containing $5 \% \beta$-mercaptoethanol and ran on a $4-20 \%$ SDS/PAGE. Gels were autoradiographed and bands were counted using a Molecular Dynamics PhosphorImager software.

\section{Immunoblotting}

Total cellular extracts $(20 \mu \mathrm{g})$ were separated by a $4-20 \%$ Tris-glycine gel then transferred to a PVDF membrane (Immobilon-P transfer membranes; Millipore Corp.) Following the transfer, the blots were blocked with $5 \%$ nonfat dry milk in PBS $+0.1 \%$ Tween-20 for $2 \mathrm{hr}$ and washed three times with PBS $+0.1 \%$ Tween- 20 at $4{ }^{\circ} \mathrm{C}$. The blots were then probed with 1:200 dilution of primary antibody against caspase-3 (H-277; Santa Cruz Biotechnology, sc-7148), PARP (H-250; Santa Cruz Biotechnology, sc-7150), CDK2 (M2; Santa Cruz Biotechnology, sc-163), cyclin A (H-432; Santa Cruz Biotechnology, sc-751), cyclin E (C-19; Santa Cruz Biotechnology, sc-198), and actin (c-11; Santa Cruz Biotechnology, sc-1615). The blots were then probed with a 1:750 dilution of secondary antibodies for $1 \mathrm{~h}$ at $4^{\circ} \mathrm{C}$, followed by washes in PBS $+0.1 \%$ Tween-20 and detected using SuperSignal West Dura Extended Duration Substrate Kit (Pierce, Rockford, IL, USA).

\section{HTLV-I pI9 ELISA}

MT-2 cells (HTLV-1 infected) were treated with TNF- $\alpha$ (10 $\mathrm{ng} / \mathrm{ml}$ ) for $2 \mathrm{~h}$, washed, and subsequently treated with a specific NF-kB or CDK inhibitor. Media from MT-2 infected cells were centrifuged to pellet the cells, and supernatants were collected and diluted to $1: 100$ to
1:1,000 in RPMI 1640 prior to ELISA. Seven days later samples were collected and used for p19 gag ELISA. The HTLV-1 p19 core antigen ELISA kit was from Retro-Tek (Cellular Products) and RT/PCR using HTLV-1 specific Tax primers (data not shown).

\section{ACH transfcetion of cells}

Log phase 293 cells were transfected with $20 \mu \mathrm{g}$ of ACH.pcTax (wild type HTLV-1 clone) using electroporation method. After transfection, the cells were cultured in complete medium supplemented with $10 \%$ fetal calf serum (FCS), $2 \mathrm{mM}$ L-glutamine, $50 \mu \mathrm{g}$ of penicillin/ml, and $50 \mathrm{U}$ of streptomycin/ml. Cell culture supernatants were collected at 4 days post-transfection, and virus particle production was monitored by p19 ELISA as described above. Drug treatment was 6 hrs after transfection of the 293 cells for a total of 150 hrs.

\section{Flow Cytometry}

For cell cycle analysis, cells treated with or without drugs were collected by low speed centrifugation and washed with PBS without $\mathrm{Ca}^{2+}$ and $\mathrm{Mg}^{2+}$ and then fixed with $70 \%$ ethanol. For fluorescence-activated cell sorting (FACS) analysis, cells were stained with a mixture of propidium iodide buffer (PBS with $\mathrm{Ca}^{2+}$ and $\mathrm{Mg}^{2+}, 10 \mu \mathrm{g} / \mathrm{ml}$ RNase A, $0.1 \%$ Nonidet P-40, and $50 \mu \mathrm{g} / \mathrm{ml}$ propidium iodide) followed by cell sorting analysis. The acquired FACS data were analyzed by ModFit LT software (Verity Software House, Inc.). Cells were washed twice with cold PBS without $\mathrm{Ca}^{2+}$ and $\mathrm{Mg}^{2+}$, resuspended in $1 \times$ binding buffer (10 $\mathrm{mM}$ HEPES-NaOH (pH 7.4), $140 \mathrm{mM} \mathrm{NaCl}, 2.5 \mathrm{mM}$ $\mathrm{CaCl}_{2}$ ) and $5 \mu \mathrm{l}$ of propidium iodide $/ 10^{5}$ cells, and incubated at room temperature for $15 \mathrm{~min}$. Cells were acquired and analyzed using CELLQuest software (BD Biosciences).

Detection of apoptosis through annexin $\mathrm{V}$ and PI staining was done according to the manufacturers protocol (BD Pharmingen, San Jose, CA). In brief, cells were washed three times in PBS and re-suspended in binding buffer at $1 \times 106$ cells $/ \mathrm{ml}$. An aliquot of $1 \times 105$ cells was stained with annexin V-FITC and PI for 15 minutes at room temperature. Analysis was performed on a BD FacsCalibur flow cytometer. Cells were considered to be early apoptotic if they exhibited staining for annexin V, but not PI. The double positive population was considered to be in the late stage of apoptosis.

\section{Competing interests}

The authors declare that they have no competing interests.

\section{Authors' contributions}

EA performed the initial drug screening assays along with WIY, WIY carried most of the subsequent confirmation and Western blots, RB, ZK, and CP carried out confirma- 
tory experiments on Westerns, FACS, as well as kinase assays, KKH and WW provided the day to day leadership and direction for the project, FK also provided the overall direction and the funding for the project.

\section{Acknowledgements}

Both E. Agbottah and W-I Yeh contributed equally to this work and share first authorship. We thank Ann Richmond and Dean Ballard (Department of Cancer Biology, Vanderbilt University) for the expression plasmids as well as the GST-IKB $\alpha$. The current research was supported by grants from the George Washington University REF funds to Akos Vertes and FK; McCormick Grant and NIH grants Al065236, Al043894 to FK.

\section{References}

I. Verdonck K, Gonzalez E, Van Dooren S, Vandamme AM, Vanham G, Gotuzzo E: Human T-lymphotropic virus I: recent knowledge about an ancient infection. Lancet Infect Dis 2007, 7:266-28I.

2. Matsuoka M, Jeang KT: Human T-cell leukaemia virus type I (HTLV-I) infectivity and cellular transformation. Nat Rev Cancer 2007, 7:270-280.

3. Peloponese JM Jr., Kinjo T, Jeang KT: Human T-cell leukemia virus type I Tax and cellular transformation. Int J Hematol 2007, 86:101-106.

4. Suzuki T, Hirai H, Yoshida M: Tax protein of HTLV-I interacts with the Rel homology domain of NF-kappa B p65 and c-Rel proteins bound to the NF-kappa B binding site and activates transcription. Oncogene 1994, 9:3099-3105.

5. Yin MJ, Christerson LB, Yamamoto Y, Kwak YT, Xu S, Mercurio F, Barbosa M, Cobb MH, Gaynor RB: HTLV-I Tax protein binds to MEKKI to stimulate IkappaB kinase activity and NF-kappaB activation. Cell 1998, 93:875-884.

6. Xiao G, Cvijic ME, Fong A, Harhaj EW, Uhlik MT, Waterfield M, Sun SC: Retroviral oncoprotein Tax induces processing of NFkappaB2/p 100 in $T$ cells: evidence for the involvement of IKKalpha. Embo / 200I, 20:6805-68I 5.

7. Caron C, Rousset R, Beraud C, Moncollin V, Egly JM, Jalinot P: Functional and biochemical interaction of the HTLV-I Tax I transactivator with TBP. Embo J 1993, I 2:4269-4278.

8. Clemens KE, Piras G, Radonovich MF, Choi KS, Duvall JF, Dejong J, Roeder R, Brady JN: Interaction of the human T-cell Iymphotropic virus type I tax transactivator with transcription factor IIA. Mol Cell Biol 1996, I 6:4656-4664.

9. Colgin MA, Nyborg JK: The human T-cell leukemia virus type I oncoprotein Tax inhibits the transcriptional activity of c-Myb through competition for the CREB binding protein. J Virol 1998, 72:9396-9399.

10. Gachon F, Thebault S, Peleraux A, Devaux C, Mesnard JM: Molecular interactions involved in the transactivation of the human T-cell leukemia virus type I promoter mediated by Tax and CREB-2 (ATF-4). Mol Cell Biol 2000, 20:3470-348I.

11. Harrod R, Tang Y, Nicot C, Lu HS, Vassilev A, Nakatani Y, Giam CZ: An exposed KID-like domain in human T-cell lymphotropic virus type I Tax is responsible for the recruitment of coactivators CBP/p300. Mol Cell Biol 1998, I 8:5052-506I.

12. Nicot C, Mahieux R, Opavsky R, Cereseto A, Wolff L, Brady JN, Franchini G: HTLV-I Tax transrepresses the human c-Myb promoter independently of its interaction with CBP or p300. Oncogene 2000, 19:2155-2164.

13. Yin MJ, Paulssen EJ, Seeler JS, Gaynor RB: Protein domains involved in both in vivo and in vitro interactions between human T-cell leukemia virus type I tax and CREB. J Virol I995, 69:3420-3432.

14. Kashanchi F, Brady JN: Transcriptional and post-transcriptional gene regulation of HTLV-I. Oncogene 2005, 24:5938-595I.

15. Aggarwal BB: Nuclear factor-kappaB: the enemy within. Cancer Cell 2004, 6:203-208.

16. Okamoto T, Sakurada S, Yang JP, Merin JP: Regulation of NFkappa $B$ and disease control: identification of a novel serine kinase and thioredoxin as effectors for signal transduction pathway for NF-kappa B activation. Curr Top Cell Regul 1997, 35:|49-|6|.
17. Basseres DS, Baldwin AS: Nuclear factor-kappaB and inhibitor of kappaB kinase pathways in oncogenic initiation and progression. Oncogene 2006, 25:6817-6830.

18. Taylor GP, Matsuoka M: Natural history of adult T-cell leukemia/lymphoma and approaches to therapy. Oncogene 2005, 24:6047-6057.

19. Ghosh S, Karin M: Missing pieces in the NF-kappaB puzzle. Cell 2002, I 09 Suppl:S8I-96.

20. Pikarsky E, Porat RM, Stein I, Abramovitch R, Amit S, Kasem S, Gutkovich-Pyest E, Urieli-Shoval S, Galun E, Ben-Neriah Y: NF-kappaB functions as a tumour promoter in inflammation-associated cancer. Nature 2004, 43 I:46I-466.

2I. Gilmore TD: Introduction to NF-kappaB: players, pathways, perspectives. Oncogene 2006, 25:6680-6684.

22. Karin M, Cao Y, Greten FR, Li ZW: NF-kappaB in cancer: from innocent bystander to major culprit. Nat Rev Cancer 2002, 2:301-310.

23. Schesser K, Spiik AK, Dukuzumuremyi JM, Neurath MF, Pettersson S, Wolf-Watz $H$ : The yopJ locus is required for Yersinia-mediated inhibition of NF-kappaB activation and cytokine expression: YopJ contains a eukaryotic SH2-like domain that is essential for its repressive activity. Mol Microbiol 1998, 28:1067-1079.

24. Pomerantz JL, Baltimore D: Two pathways to NF-kappaB. Mol Cell 2002, 10:693-695.

25. Mori N, Yamada Y, Ikeda S, Yamasaki Y, Tsukasaki K, Tanaka Y, Tomonaga M, Yamamoto N, Fujii M: Bay II-7082 inhibits transcription factor NF-kappaB and induces apoptosis of HTLV. I-infected $T$-cell lines and primary adult $T$-cell leukemia cells. Blood 2002, 100:1828-1834.

26. Mori N, Fujii M, Iwai K, Ikeda S, Yamasaki Y, Hata T, Yamada Y, Tanaka $Y$, Tomonaga $M$, Yamamoto $N$ : Constitutive activation of transcription factor AP-I in primary adult T-cell leukemia cells. Blood 2000, 95:3915-3921.

27. Bonizzi G, Bebien M, Otero DC, Johnson-Vroom KE, Cao Y, Vu D, Jegga AG, Aronow BJ, Ghosh G, Rickert RC, Karin M: Activation of IKKalpha target genes depends on recognition of specific kappaB binding sites by RelB:p52 dimers. Embo J 2004, 23:4202-4210.

28. Derudder E, Dejardin E, Pritchard LL, Green DR, Korner M, Baud V: RelB/p50 dimers are differentially regulated by tumor necrosis factor-alpha and lymphotoxin-beta receptor activation: critical roles for p 100. J Biol Chem 2003, 278:23278-23284.

29. Yilmaz ZB, Weih DS, Sivakumar V, Weih F: RelB is required for Peyer's patch development: differential regulation of $\mathrm{p52}$ RelB by lymphotoxin and TNF. Embo J 2003, 22: I 2 | - I 30.

30. Schwabe RF, Schnabl B, Kweon YO, Brenner DA: CD40 activates NF-kappa $B$ and c-Jun $\mathbf{N}$-terminal kinase and enhances chemokine secretion on activated human hepatic stellate cells. J Immunol 200I, I 66:6812-6819.

31. Hironaka N, Mochida K, Mori N, Maeda M, Yamamoto N, Yamaoka S: Tax-independent constitutive IkappaB kinase activation in adult T-cell leukemia cells. Neoplasia 2004, 6:266-278.

32. Chu ZL, Shin YA, Yang JM, DiDonato JA, Ballard DW: IKKgamma mediates the interaction of cellular IkappaB kinases with the tax transforming protein of human $T$ cell leukemia virus type I. J Biol Chem I999, 274:I5297-15300.

33. Harhaj EW, Sun SC: IKKgamma serves as a docking subunit of the IkappaB kinase (IKK) and mediates interaction of IKK with the human T-cell leukemia virus Tax protein. J Biol Chem |999, 274:229| |-229|4.

34. Jin DY, Giordano V, Kibler KV, Nakano H, Jeang KT: Role of adapter function in oncoprotein-mediated activation of NFkappaB. Human T-cell leukemia virus type I Tax interacts directly with IkappaB kinase gamma. J Biol Chem 1999, 274: I7402- 17405 .

35. Yamaoka S, Courtois G, Bessia C, Whiteside ST, Weil R, Agou F, Kirk $\mathrm{HE}$, Kay RJ, Israel A: Complementation cloning of NEMO, a component of the IkappaB kinase complex essential for NFkappaB activation. Cell 1998, 93:123I-I240.

36. Karunagaran D. ABB: Transcription factors as targets fr the drug development. In Molecular pathomechanisms and new trends in drug development Edited by: Keri G. TI. New York, NY, Harwood Academic Publisher; 2002:76-91. 
37. Mori N, Fujii M, Ikeda S, Yamada Y, Tomonaga M, Ballard DW, Yamamoto N: Constitutive activation of NF-kappaB in primary adult T-cell leukemia cells. Blood 1999, 93:2360-2368.

38. Nicot C, Mahieux R, Takemoto S, Franchini G: Bcl-X(L) is up-regulated by HTLV-I and HTLV-II in vitro and in ex vivo ATLL samples. Blood 2000, 96:275-28I.

39. Dewan MZ, Terashima K, Taruishi M, Hasegawa H, Ito M, Tanaka $Y$, Mori N, Sata T, Koyanagi Y, Maeda M, Kubuki Y, Okayama A, Fujii M, Yamamoto N: Rapid tumor formation of human T-cell leukemia virus type I-infected cell lines in novel NOD-SCID/gammac(null) mice: suppression by an inhibitor against NFkappaB. J Virol 2003, 77:5286-5294.

40. Ohsugi T, Horie R, Kumasaka T, Ishida A, Ishida T, Yamaguchi K, Watanabe T, Umezawa K, Urano T: In vivo antitumor activity of the NF-kappaB inhibitor dehydroxymethylepoxyquinomicin in a mouse model of adult T-cell leukemia. Carcinogenesis 2005, 26: $1382-1388$.

4l. Watanabe M, Ohsugi T, Shoda M, Ishida T, Aizawa S, Maruyama-Nagai M, Utsunomiya A, Koga S, Yamada Y, Kamihira S, Okayama A, Kikuchi H, Uozumi K, Yamaguchi K, Higashihara M, Umezawa K, Watanabe T, Horie R: Dual targeting of transformed and untransformed HTLV-I-infected T cells by DHMEQ, a potent and selective inhibitor of NF-kappaB, as a strategy for chemoprevention and therapy of adult T-cell leukemia. Blood 2005, I 06:2462-247I.

42. Ohsugi T, Kumasaka T, Ishida A, Ishida T, Horie R, Watanabe T, Umezawa $\mathrm{K}$, Yamaguchi $\mathrm{K}$ : In vitro and in vivo antitumor activity of the NF-kappaB inhibitor DHMEQ in the human T-cell leukemia virus type I-infected cell line, HUT-I02. Leuk Res 2006, 30:90-97.

43. El-Sabban ME, Nasr R, Dbaibo G, Hermine O, Abboushi N, Quignon $F$, Ameisen JC, Bex F, de The H, Bazarbachi A: Arsenic-interferonalpha-triggered apoptosis in HTLV-I transformed cells is associated with tax down-regulation and reversal of NFkappa B activation. Blood 2000, 96:2849-2855.

44. Nasr R, Rosenwald A, El-Sabban ME, Arnulf B, Zalloua P, Lepelletier Y, Bex F, Hermine O, Staudt L, de The H, Bazarbachi A: Arsenicl interferon specifically reverses 2 distinct gene networks critical for the survival of HTLV-I-infected leukemic cells. Blood 2003, I 0 I:4576-4582.

45. Satou Y, Nosaka K, Koya Y, Yasunaga Jl, Toyokuni S, Matsuoka M: Proteasome inhibitor, bortezomib, potently inhibits the growth of adult T-cell leukemia cells both in vivo and in vitro. Leukemia 2004, I 8: I357-I363.

46. Lemoine FJ, Marriott S): Accelerated G(I) phase progression induced by the human T cell leukemia virus type I (HTLV-I) Tax oncoprotein. J Biol Chem 200I, 276:3185I-31857.

47. Suzuki T, Kitao S, Matsushime H, Yoshida M: HTLV-I Tax protein interacts with cyclin-dependent kinase inhibitor pI6INK4A and counteracts its inhibitory activity towards CDK4. Embo J 1996, I5:1607-1614

48. Parker SF, Perkins ND, Gitlin SD, Nabel GJ: A cooperative interaction of human T-cell leukemia virus type I Tax with the p2 I cyclin-dependent kinase inhibitor activates the human immunodeficiency virus type I enhancer. J Virol 1996, 70:573|-5734

49. Low KG, Dorner LF, Fernando DB, Grossman J, Jeang KT, Comb MJ: Human T-cell leukemia virus type I Tax releases cell cycle arrest induced by p I6INK4a. J Virol I997, 7 I:1956-1962.

50. Jeang KT, Giam CZ, Majone F, Aboud M: Life, death, and tax: role of HTLV-I oncoprotein in genetic instability and cellular transformation. J Biol Chem 2004, 279:31991-31994.

5I. Marriott SJ, Semmes OJ: Impact of HTLV-I Tax on cell cycle progression and the cellular DNA damage repair response. Oncogene 2005, 24:5986-5995.

52. de La Fuente C, Santiago F, Chong SY, Deng L, Mayhood T, Fu P, Stein D, Denny T, Coffman F, Azimi N, Mahieux R, Kashanchi F: Overexpression of p2I(wafl) in human T-cell lymphotropic virus type I-infected cells and its association with cyclin A/cdk2. J Virol 2000, 74:7270-7283.

53. Cereseto A, Diella F, Mulloy JC, Cara A, Michieli P, Grassmann R, Franchini G, Klotman ME: p53 functional impairment and high p2 I wafl/cip I expression in human T-cell lymphotropicl leukemia virus type I-transformed T cells. Blood 1996, 88: $|55|-1560$
54. Pise-Masison CA, Radonovich M, Sakaguchi K, Appella E, Brady JN: Phosphorylation of p53: a novel pathway for p53 inactivation in human T-cell lymphotropic virus type I-transformed cells. J Virol 1998, 72:6348-6355.

55. Pise-Masison CA, Mahieux R, Jiang $H$, Ashcroft $M$, Radonovich $M$, Duvall J, Guillerm C, Brady JN: Inactivation of p53 by human $T$. cell lymphotropic virus type I Tax requires activation of the NF-kappaB pathway and is dependent on p53 phosphorylation. Mol Cell Biol 2000, 20:3377-3386.

56. Neuveut C, Low KG, Maldarelli F, Schmitt I, Majone F, Grassmann R, Jeang KT: Human T-cell leukemia virus type I Tax and cell cycle progression: role of cyclin D-cdk and pl IORb. Mol Cell Biol 1998, 18:3620-3632.

57. Akagi T, Ono H, Shimotohno K: Expression of cell-cycle regulatory genes in HTLV-I infected T-cell lines: possible involvement of Tax I in the altered expression of cyclin D2, p I 8 Ink4 and p2 IWafI/Cip I/Sdi I. Oncogene 1996, I 2: I645-1652.

58. de La Fuente C, Deng L, Santiago F, Arce L, Wang L, Kashanchi F: Gene expression array of HTLV type I-infected T cells: Upregulation of transcription factors and cell cycle genes. AIDS Res Hum Retroviruses 2000, I 6: I695-1700.

59. Huang Y, Ohtani K, Iwanaga R, Matsumura Y, Nakamura M: Direct trans-activation of the human cyclin $D 2$ gene by the oncogene product Tax of human T-cell leukemia virus type $I$. Oncogene 2001, 20:1094-II02.

60. Santiago F, Clark E, Chong S, Molina C, Mozafari F, Mahieux R, Fujii $M$, Azimi N, Kashanchi F: Transcriptional up-regulation of the cyclin D2 gene and acquisition of new cyclin-dependent kinase partners in human $\mathbf{T}$-cell leukemia virus type Iinfected cells. J Virol 1999, 73:9917-9927.

6I. Iwanaga R, Ohtani K, Hayashi T, Nakamura M: Molecular mechanism of cell cycle progression induced by the oncogene product Tax of human T-cell leukemia virus type I. Oncogene 200I, 20:2055-2067.

62. Kehn K, Deng L, de la Fuente C, Strouss K, Wu K, Maddukuri A, Baylor S, Rufner R, Pumfery A, Bottazzi ME, Kashanchi F: The role of cyclin D2 and p2I/wafl in human T-cell leukemia virus type I infected cells. Retrovirology 2004, I:6.

63. Chlichlia K, Moldenhauer G, Daniel PT, Busslinger M, Gazzolo L, Schirrmacher $V$, Khazaie $K$ : Immediate effects of reversible HTLV-I tax function: T-cell activation and apoptosis. Oncogene 1995, 10:269-277.

64. Burke JR, Pattoli MA, Gregor KR, Brassil PJ, MacMaster JF, Mclntyre KW, Yang X, lotzova VS, Clarke W, Strnad J, Qiu Y, Zusi FC: BMS$\mathbf{3 4 5 5 4}$ I is a highly selective inhibitor of I kappa B kinase that binds at an allosteric site of the enzyme and blocks NF-kappa B-dependent transcription in mice. I Biol Chem 2003, 278: |450-|456.

65. Yang J, Amiri KI, Burke JR, Schmid JA, Richmond A: BMS-34554I targets inhibitor of kappaB kinase and induces apoptosis in melanoma: involvement of nuclear factor kappaB and mitochondria pathways. Clin Cancer Res 2006, I 2:950-960.

66. Petropoulos C], Givol I, Hughes SH: Comparative analysis of the structure and function of the chicken c-myc and v-myc genes: v-myc is a more potent inducer of cell proliferation and apoptosis than c-myc. Oncogene 1996, I2:26| |-262I.

67. Mauxion F, Jamieson C, Yoshida M, Arai K, Sen R: Comparison of constitutive and inducible transcriptional enhancement mediated by kappa B-related sequences: modulation of activity in B cells by human T-cell leukemia virus type I tax gene. Proc Natl Acad Sci U S A 1991, 88:2 I4I-2I 45

68. Arima N, Molitor JA, Smith MR, Kim JH, Daitoku Y, Greene WC: Human T-cell leukemia virus type I Tax induces expression of the Rel-related family of kappa B enhancer-binding proteins: evidence for a pretranslational component of regulation. J Virol 1991, 65:6892-6899.

69. Nicholson DW, Ali A, Thornberry NA, Vaillancourt JP, Ding CK, Gallant M, Gareau Y, Griffin PR, Labelle M, Lazebnik YA, et al.: Identification and inhibition of the ICE/CED-3 protease necessary for mammalian apoptosis. Nature 1995, 376:37-43.

70. Han Z, Hendrickson EA, Bremner TA, Wyche JH: A sequential two-step mechanism for the production of the mature p 17:pl2 form of caspase-3 in vitro. I Biol Chem 1997, 272:13432-13436.

7I. Rice WG, Hillyer CD, Harten B, Schaeffer CA, Dorminy M, Lackey DA 3rd, Kirsten E, Mendeleyev J, Buki KG, Hakam A, et al.: Induction 
of endonuclease-mediated apoptosis in tumor cells by $C$ nitroso-substituted ligands of poly(ADP-ribose) polymerase. Proc Natl Acad Sci U S A 1992, 89:7703-7707.

72. Lazebnik YA, Kaufmann SH, Desnoyers S, Poirier GG, Earnshaw WC: Cleavage of poly(ADP-ribose) polymerase by a proteinase with properties like ICE. Nature 1994, 37 I:346-347.

73. Kaufmann SH, Desnoyers S, Ottaviano Y, Davidson NE, Poirier GG: Specific proteolytic cleavage of poly(ADP-ribose) polymerase: an early marker of chemotherapy-induced apoptosis. Cancer Res 1993, 53:3976-3985.

74. Sherr CJ, Roberts JM: CDK inhibitors: positive and negative regulators of GI-phase progression. Genes Dev 1999, 13:1501-1512.

75. Villerbu N, Gaben AM, Redeuilh G, Mester J: Cellular effects of purvalanol A: a specific inhibitor of cyclin-dependent kinase activities. Int J Cancer 2002, 97:761-769.

76. Bain J, McLauchlan H, Elliott M, Cohen P: The specificities of protein kinase inhibitors: an update. Biochem J 2003, 37 I: 199-204.

77. Gray NS, Wodicka L, Thunnissen AM, Norman TC, Kwon S, Espinoza FH, Morgan DO, Barnes G, LeClerc S, Meijer L, Kim SH, Lockhart DJ, Schultz PG: Exploiting chemical libraries, structure, and genomics in the search for kinase inhibitors. Science 1998, 28 I:533-538.

78. Matsuoka M, Jeang KT: Human T-cell leukemia virus type $\mathbf{I}$ at age 25: a progress report. Cancer Res 2005, 65:4467-4470.

79. Sun SC, Yamaoka S: Activation of NF-kappaB by HTLV-I and implications for cell transformation. Oncogene 2005, 24:5952-5964.

80. Kudoh A, Daikoku T, Sugaya $Y$, Isomura H, Fujita M, Kiyono T, Nishiyama $Y$, Tsurumi $T$ : Inhibition of S-phase cyclin-dependent kinase activity blocks expression of Epstein-Barr virus immediate-early and early genes, preventing viral lytic replication. J Virol 2004, 78: I04-I I5.

8I. Wang L, Deng L, Wu K, de la Fuente C, Wang D, Kehn K, Maddukuri A, Baylor S, Santiago F, Agbottah E, Trigon S, Morange M, Mahieux R, Kashanchi F: Inhibition of HTLV-I transcription by cyclin dependent kinase inhibitors. Mol Cell Biochem 2002, 237:137-I53.

82. Gill PS, Harrington W Jr., Kaplan MH, Ribeiro RC, Bennett JM, Liebman HA, Bernstein-Singer M, Espina BM, Cabral L, Allen S, et al.: Treatment of adult T-cell leukemia-lymphoma with a combination of interferon alfa and zidovudine. N Engl ] Med 1995, 332: $1744-1748$.

83. Hermine O, Bouscary D, Gessain A, Turlure P, Leblond V, Franck N, Buzyn-Veil A, Rio B, Macintyre E, Dreyfus F, et al: Brief report: treatment of adult T-cell leukemia-lymphoma with zidovudine and interferon alfa. N Engl J Med 1995, 332: 1749-I75।.

84. Bazarbachi A, Hermine O: Treatment with a combination of zidovudine and alpha-interferon in naive and pretreated adult T-cell leukemia/lymphoma patients. J Acquir Immune Defic Syndr Hum Retrovirol 1996, I 3 Suppl I:SI86-90.

85. Hermine O, Allard I, Levy V, Arnulf B, Gessain A, Bazarbachi A: A prospective phase II clinical trial with the use of zidovudine and interferon-alpha in the acute and lymphoma forms of adult T-cell leukemia/lymphoma. Hematol J 2002, 3:276-282.

86. Hermine $O$, Dombret $H$, Poupon J, Arnulf $B$, Lefrere $F$, Rousselot $P$, Damaj G, Delarue R, Fermand JP, Brouet JC, Degos L, Varet B, de The $H$, Bazarbachi A: Phase II trial of arsenic trioxide and alpha interferon in patients with relapsed/refractory adult T-cell leukemia/lymphoma. Hematol J 2004, 5: I30-134.

87. Kfoury $Y$, Nasr R, Hermine O, de The H, Bazarbachi A: Proapoptotic regimes for HTLV-I-transformed cells: targeting Tax and the NF-kappaB pathway. Cell Death Differ 2005, I 2 Suppl I:87|-877.
Publish with Bio Med Central and every scientist can read your work free of charge

"BioMed Central will be the most significant development for disseminating the results of biomedical research in our lifetime. "

Sir Paul Nurse, Cancer Research UK

Your research papers will be:

- available free of charge to the entire biomedical community

- peer reviewed and published immediately upon acceptance

- cited in PubMed and archived on PubMed Central

- yours - you keep the copyright

Submit your manuscript here:

http://www.biomedcentral.com/info/publishing_adv.asp
BiolMedcentral 